\title{
Solid-Phase Synthesis of Biaryl Cyclic Lipopeptides Derived from Arylomycins
}

\author{
Iteng Ng-Choi, Eduard Figueras, Àngel Oliveras, Lidia Feliu,* and Marta Planas*
}

Cite This: ACS Omega 2020, 5, 23401-23412

Read Online

\section{ACCESS}

Џlll Metrics \& More

回 Article Recommendations

Supporting Information
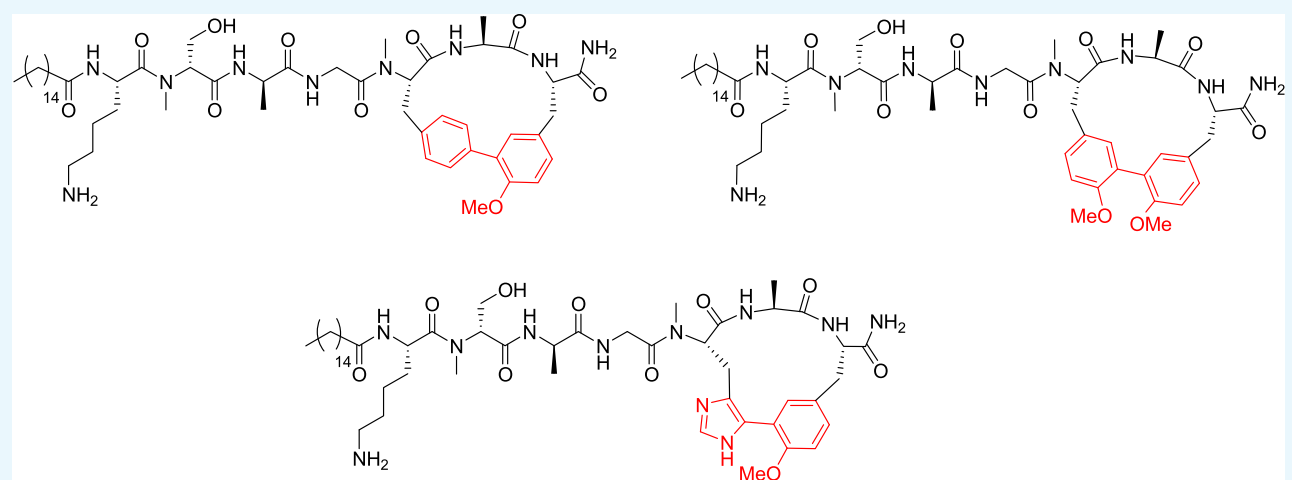

ABSTRACT: An efficient approach for the solid-phase synthesis of N-methylated tailed biaryl cyclic lipopeptides based on the structure of arylomycins was established. Each of these analogues incorporates an N-terminal linear lipopeptide attached to a biaryl cyclic tripeptide containing a Phe-Tyr, a Tyr-Tyr, or a His-Tyr linkage. This methodology first involved an intramolecular Suzuki-Miyaura arylation of a linear peptidyl resin incorporating the corresponding halogenated amino acid at the N-terminus and a boronotyrosine at the $\mathrm{C}$-terminus. After $\mathrm{N}$-methylation of the resulting biaryl cyclic peptidyl resin, the N-methylated lipopeptidyl tail was then assembled. The biaryl cyclic lipopeptides were purified and characterized.

\section{INTRODUCTION}

Biaryl cyclic peptides have been shown to provide a promising scaffold for the development of novel drugs, owing to their target selectivity, binding affinity, and low toxicity. Thus, they have attracted attention from fields including medicinal chemistry and chemical biology. ${ }^{1,2}$ The aryl-aryl bonds in these compounds commonly involve the linkage between the side chains of two aromatic amino acids. Among natural biaryl cyclic peptides, arylomycins $\mathrm{A}$ and $\mathrm{B}$ are a class of biarylcontaining peptide antibiotics that contain a lipopeptidyl tail attached to a biaryl cyclic tripeptide core. ${ }^{3-6}$ The peptidyl tail is a tripeptide with the $\mathrm{N}$-terminus methylated and acylated with a fatty acid of $12-16$ carbon atoms. The cyclic core contains an $\mathrm{N}$-methylated residue and incorporates a biaryl linkage between a 4-hydroxy-L-phenylglycine derivative and a tyrosine residue (Figure 1). In particular, the $A$ series of arylomycins possesses an unmodified core, while the compounds of the $\mathrm{B}$ series have a nitro substituent on the phenol ring of tyrosine. Arylomycins were isolated from the fermentation broth of Streptomyces sp. Tü 6075 and display significant activity against a variety of Gram-positive and Gram-negative bacteria that results from the inhibition of bacterial type I signal peptidase (SPase). In addition, it has been shown that, even at sub-minimal inhibitory concentration (MIC) levels, arylomycins are able to inhibit a range of<smiles>[R]C(=O)N(C)[C@@H](CO)C(=O)N[C@@H](C)C(=O)NCC(=O)N(C)[C@H]1C(=O)N[C@@H](C)C(=O)N[C@@H](C(=O)O)Cc2cc([R])c(O)c(c2)-c2cccc(O)c21</smiles>

$\begin{array}{ll}\text { Arylomycins A } & \mathrm{R}^{1}=\mathrm{H} ; \mathrm{R}^{2}=\text { fatty acid chain } \\ \text { Arylomycins B } & \mathrm{R}^{1}=\mathrm{NO}_{2} ; \mathrm{R}^{2}=\text { fatty acid chain }\end{array}$

Figure 1. Structure of arylomycins A and B.

virulence processes as well as the dissemination of resistance. ${ }^{3-12}$

The structural features of arylomycins in conjunction with their significant biological activities have prompted scientists to

Received: July 13, 2020

Accepted: August 12, 2020

Published: September 4, 2020 


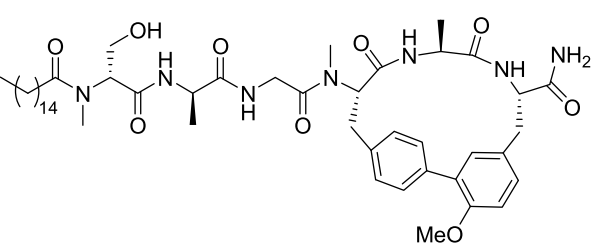

1

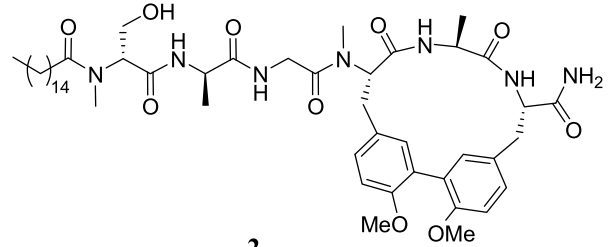

2

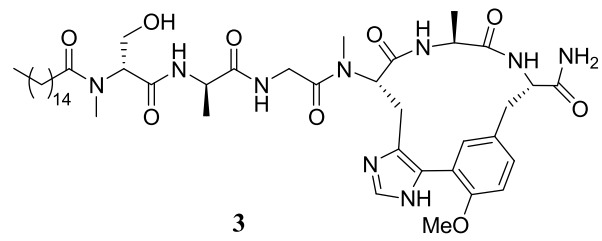

Figure 2. Structure of $\mathrm{N}$-methylated tailed biaryl cyclic lipopeptides 1-3.

Scheme 1. Retrosynthetic Analysis of the Biaryl Cyclic Lipopeptides 1-3
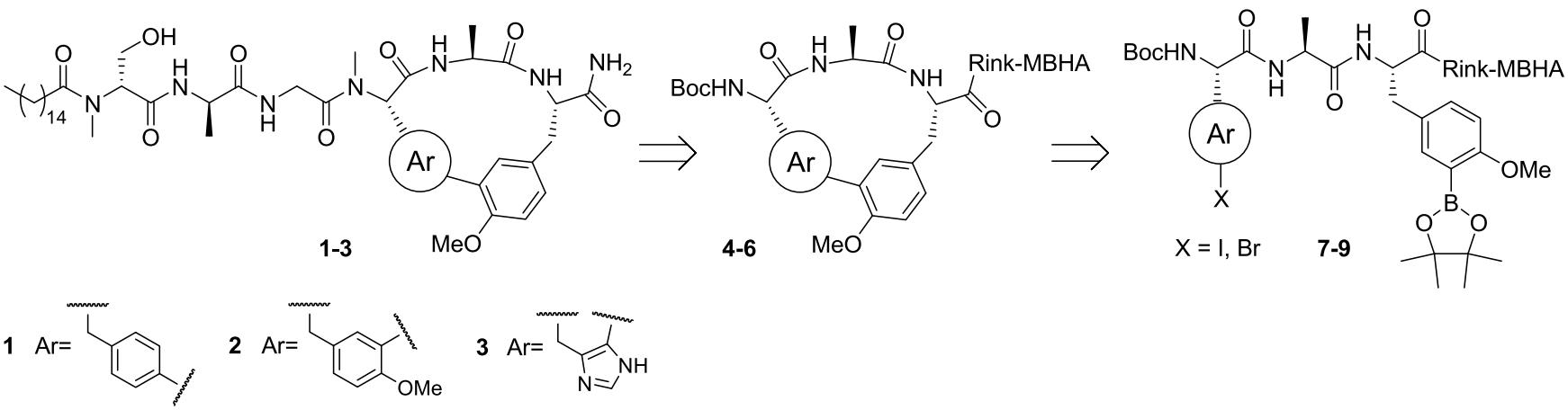

develop efficient methods to obtain these compounds and a diversity of analogues. ${ }^{4-6,13-21}$ In particular, Romesberg and co-workers reported the total synthesis of arylomycin $A_{2}$ in solution. ${ }^{4}$ They proposed two strategies that differed in the macrocyclization step for the formation of the biaryl macrocyclic tripeptide core. This step was performed by standard macrolactamization of a conveniently protected biaryl linear tripeptide. Alternatively, the cyclization was carried out through an intramolecular Suzuki-Miyaura cross-coupling of a tripeptide containing a 3-iodo-L-phenylglycine and a 3-boronoL-tyrosine. The latter macrocyclization strategy resulted in being the most successful. The lipopeptidyl tail was then assembled to the biaryl core providing arylomycin $\mathrm{A}_{2}$. A similar strategy was reported by $\mathrm{Zhu}$ and co-workers for the total synthesis of arylomycins $A_{2}$ and $B_{2}$ via an intramolecular Suzuki-Miyaura reaction. ${ }^{24}$ These methodologies were extended to the preparation of other arylomycins ${ }^{5,6}$ and derivatives. $^{15,16}$ Recent reports have been focused on optimizing the synthesis of the macrocyclic core of arylomycins. To this end, Romesberg and Baran have described the scalable macrocyclization of the Hpg-Ala-Tyr precursor using a stoichiometric $\mathrm{Cu}$-mediated oxidative coupling. ${ }^{17} \mathrm{Lim}$ and co-workers have developed protocols for the preparation of the macrocyclic core of arylomycins using amide bond formation or a Suzuki-Miyaura cross-coupling for the macrocyclization step. ${ }^{19,20}$ More recently, the Pappo group has devised a three-step synthesis for the cyclic core involving an activating-group-assisted catalytic oxidative coupling for the formation of the biaryl bond followed by macrolactamization. ${ }^{21}$

Since conventional solution-phase synthesis requires very long and tedious work-up procedures and troublesome purifications after each reaction step, the solid-phase peptide synthesis has become a more powerful method for accelerating such a process. ${ }^{22}$ Moreover, solid-supported chemistry has the additional advantage of allowing the preparation of analogues in a convenient and flexible manner. However, to the best of our knowledge, the solid-phase synthesis of arylomycins has not yet been reported. In fact, the preparation of biaryl peptides on a solid support has been scarcely developed. ${ }^{23-28}$ In this context and within our interest in the synthesis of biaryl peptides, since 2008 we have established methodologies for the preparation of biaryl cyclic peptides centered on the formation of the aryl-aryl bond through a solid-phase Suzuki-Miyaura cross-coupling. ${ }^{29}$ We chose this reaction for the formation of the biaryl bond because of its widely reported advantages. In particular, we have described the synthesis of linear and cyclic peptides containing a biaryl bond between the side chains of a Phe, a Tyr, or a His residue. ${ }^{30-36}$ Based on the interest arisen from arylomycins, we decided to extend our solid-phase methodology to the preparation of biaryl cyclic lipopeptides related to arylomycins. In particular, we focused our attention on analogues $1-3$, which contain a Phe-Tyr, a Tyr-Tyr, or a His-Tyr biaryl linkage, respectively (Figure 2).

\section{RESULTS AND DISCUSSION}

Retrosynthetic Analysis. The solid-phase synthesis of the biaryl cyclic lipopeptides 1-3 was planned according to the retrosynthetic analysis depicted in Scheme 1. It would involve the synthesis of the biaryl cyclic peptidyl resins 4-6 through intramolecular Suzuki-Miyaura cross-coupling of the tripeptidyl resins 7-9, incorporating a boronotyrosine and a halogenated aromatic amino acid. Subsequent N-methylation of 4-6, elongation of the peptidyl tail, methylation of the N- 
Scheme 2. Synthesis of the Biaryl Cyclic Tripeptidyl Resins 4-6
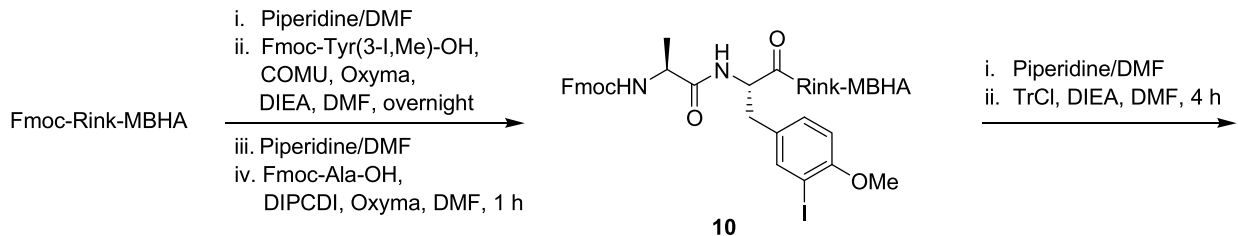

10

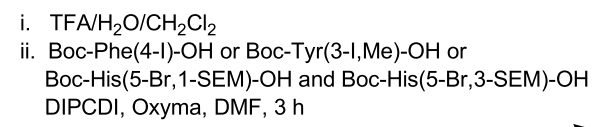

$\mathrm{B}_{2} \mathrm{Pin}_{2,} \mathrm{PdCl}_{2}$ (dppf) dppf, KOAc, DMSO, $80^{\circ} \mathrm{C}, 8 \mathrm{~h}$

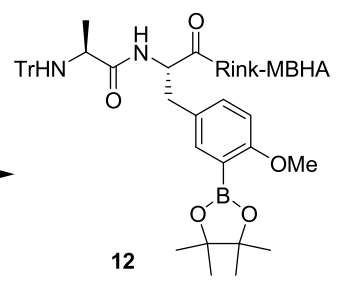

DIPCDI, Oxyma, DMF, $3 \mathrm{~h}$
DME/EtOH $/ \mathrm{H}_{2} \mathrm{O}$, $\mathrm{MW}, 120$ or $140^{\circ} \mathrm{C}, 30 \mathrm{~min}$
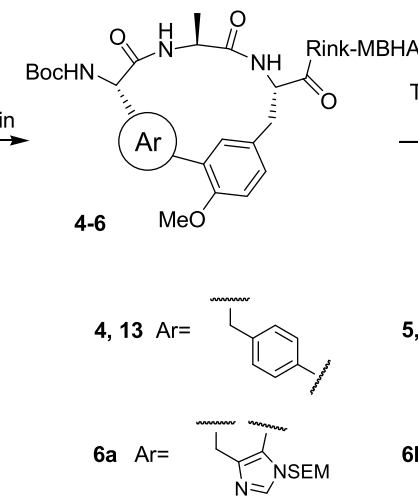

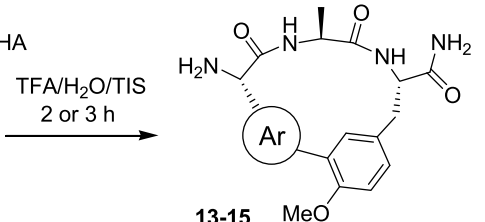

$5,14 \mathrm{Ar}=\mathrm{C}_{\mathrm{OMe}}^{\mathrm{n}}$

$6 \mathrm{~b} \quad \mathrm{Ar}=\mathrm{SEMN}_{\mathrm{N}}$

$$
15 \mathrm{Ar}=\sum_{\mathrm{N}=1}^{m \mathrm{NH}}
$$
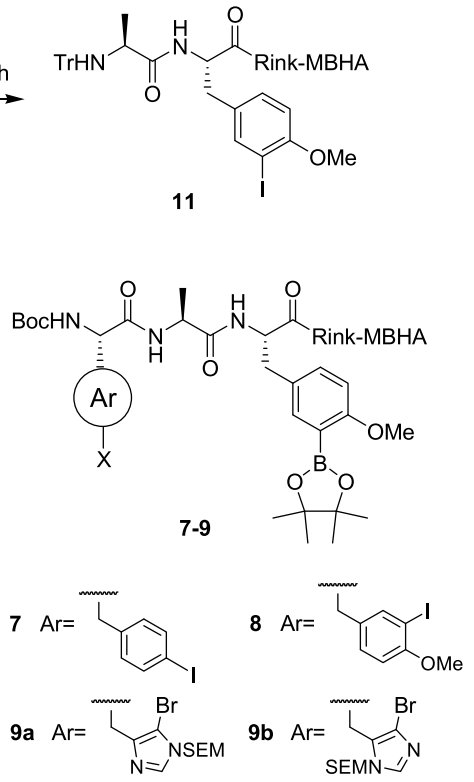

11 terminus, and cleavage would render the biaryl cyclic lipopeptides 1-3.-

Synthesis of the Biaryl Cyclic Peptidyl Resins 4-6. According to the retrosynthetic analysis, the preparation of biaryl cyclic lipopeptides $1-3$ required the synthesis of biaryl cyclic peptidyl resins 4-6 (Scheme 1). We first investigated the preparation of 4 , bearing a Phe-Tyr linkage, from the tripeptidyl resin Boc-Phe(4-I)-Ala-Tyr(3-BPin,Me)-RinkMBHA (7), which incorporates a 3-boronotyrosine and a 4iodophenylalanine (Scheme 2). The synthesis of 7 started from an Fmoc-Rink-MBHA resin $(0.4 \mathrm{mmol} / \mathrm{g})$ and followed a standard 9-fluorenylmethoxycarbonyl (Fmoc)/tert-butyl $(t \mathrm{Bu})$ strategy. First, the dipeptidyl resin Fmoc-Ala-Tyr(3-I,Me)Rink-MBHA (10) was obtained through sequential Fmoc removal and coupling steps. The Fmoc group was removed by treatment with piperidine/dimethylformamide (DMF) (3:7); coupling of Fmoc-Tyr(3-I,Me)-OH ${ }^{36}$ was mediated by 1-[(1(cyano-2-ethoxy-2-oxoethylidinea minooxy)dimethylaminomorpholino)] uronium hexafluorophosphate (COMU), ethyl 2-cyano-2-(hydroxyimino)acetate (Oxyma), and $N, N$-diisopropylethylamine (DIEA) in DMF; and FmocAla-OH was coupled using $N, N^{\prime}$-diisopropylcarbodiimide (DIPCDI) and Oxyma in DMF. An aliquot of resin 10 was treated with trifluoroacetic acid (TFA) $/ \mathrm{H}_{2} \mathrm{O} /$ triisoprylsilane (TIS) (95:2.5:2.5) for $2 \mathrm{~h}$ at room temperature, providing Fmoc-Ala-Tyr(3-I,Me)- $\mathrm{NH}_{2}$ in $98 \%$ purity. Then, the Fmoc group of $\mathbf{1 0}$ was replaced by a trityl $(\mathrm{Tr})$ group due to the lability of the former to the basic reaction conditions of the next borylation step. After deprotection of 10, tritylation of the resulting resin was performed with trityl chloride $(\mathrm{TrCl})$ and
DIEA in DMF, leading to resin Tr-Ala-Tyr(3-I,Me)-RinkMBHA (11). Acidolytic cleavage of an aliquot of this resin gave $\mathrm{H}$-Ala- $\mathrm{Tyr}(3-\mathrm{I}, \mathrm{Me})-\mathrm{NH}_{2}$ in $92 \%$ purity. Next, 11 was subjected to Miyaura borylation by exposure to the conditions previously described in our group, which involve the use of bis(pinacolato)diboron $\left(\mathrm{B}_{2} \mathrm{Pin}_{2}\right)$ (4 equiv), $\mathrm{PdCl}_{2}$ (dppf) (0.18 equiv), 1,1'-bis(diphenylphosphanyl)ferrocene (dppf) (0.09 equiv), and KOAc (6 equiv) in anhydrous dimethyl sulfoxide (DMSO) at $80^{\circ} \mathrm{C}$ for $8 \mathrm{~h}^{34}$ We observed that longer reaction times led to the protodeborylation of the corresponding linear precursor. Acidolytic cleavage of an aliquot of the resulting resin Tr-Ala-Tyr(3-BPin,Me)-Rink-MBHA (12) yielded the expected borono peptide $\mathrm{H}$-Ala- $\mathrm{Tyr}\left(3-\mathrm{B}(\mathrm{OH})_{2}, \mathrm{Me}\right)-\mathrm{NH}_{2}$ in $72 \%$ purity. This boronic acid resulted from the hydrolysis of the pinacol boronic ester during high-performance liquid chromatography (HPLC) analysis, which was confirmed by mass spectrometry. Next, selective trityl group removal of $\mathbf{1 2}$ by treatment with TFA $/ \mathrm{H}_{2} \mathrm{O} / \mathrm{CH}_{2} \mathrm{Cl}_{2}$ (0.2:1:98.8), followed by coupling of Boc-Phe(4-I)-OH ${ }^{37}$ using DIPCDI and Oxyma in DMF for $3 \mathrm{~h}$, provided the tripeptidyl resin Boc-Phe(4-I)Ala-Tyr(3-BPin,Me)-Rink-MBHA (7). An aliquot of this resin was acidolytically cleaved, affording H-Phe(4-I)-Ala-Tyr(3$\left.\mathrm{B}(\mathrm{OH})_{2}, \mathrm{Me}\right)-\mathrm{NH}_{2}$ in $81 \%$ purity, which was characterized by mass spectrometry.

Based on our previous experience on the synthesis of biaryl cyclic peptides containing a Phe-Tyr linkage, ${ }^{34}$ macrocyclization of the linear peptidyl resin 7 was achieved via a Suzuki-Miyaura cross-coupling using $\operatorname{Pd}_{2}(\mathrm{dba})_{3}$ ( 0.2 equiv) as the catalyst, SPhos ( 0.4 equiv) as the ligand, and KF ( 4 equiv) as the base in degassed 1,2-dimethoxyethane (DME)/EtOH/ 
Scheme 3. Synthesis of Biaryl Cyclic Lipopeptides 1-3

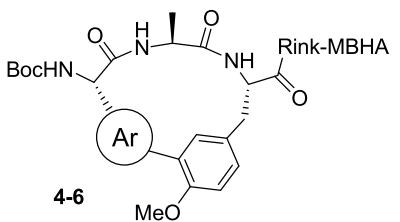
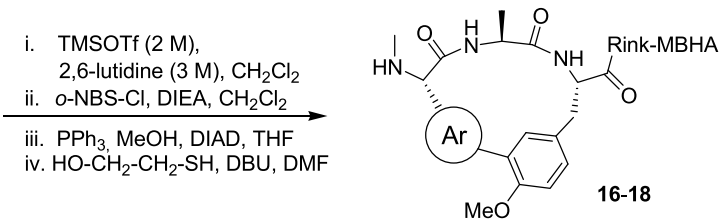

Sequential steps

DIPCDI, Oxyma, DMF

ii. Piperidine/DMF
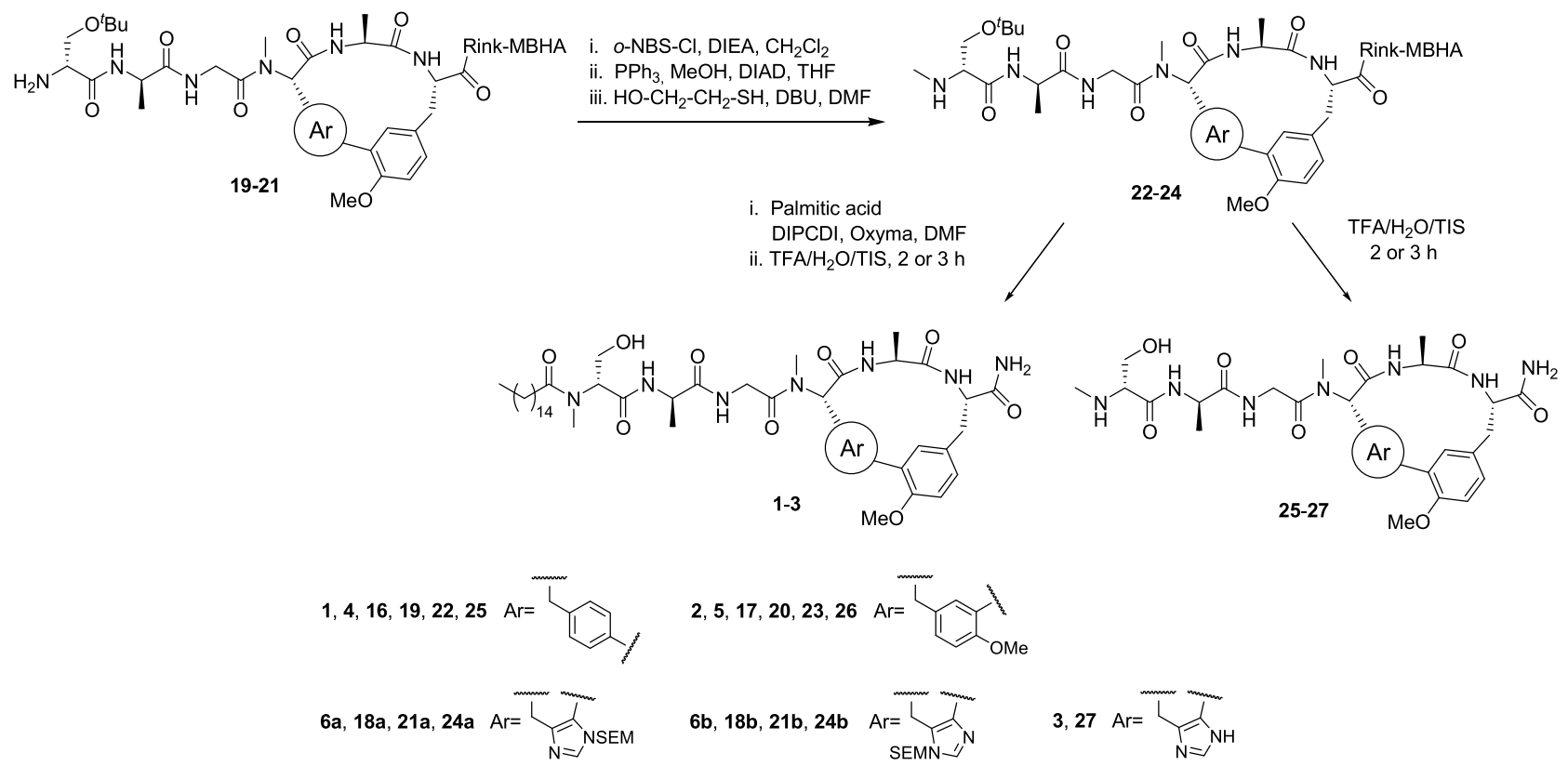

6b, 18b, 21b, 24b $A r=$

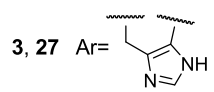

$\mathrm{H}_{2} \mathrm{O}$ (9:9:2) under microwave irradiation at $120{ }^{\circ} \mathrm{C}$ for $30 \mathrm{~min}$ (Scheme 2). Giralt and co-workers reported that the presence of Buchwald's SPhos ligand avoids racemization of $\alpha$-amino acids, such as tyrosine derivatives in Suzuki-Miyaura reactions. ${ }^{38}$ An aliquot of the resulting resin 4 was cleaved, and HPLC and mass spectrometry analysis of the crude reaction mixture revealed the formation of the expected biaryl cyclic tripeptide 13 in $92 \%$ purity together with traces of the protodeborylated byproduct $\mathrm{H}-\mathrm{Phe}(4-\mathrm{I})-\mathrm{Ala}-\mathrm{Tyr}(\mathrm{Me})-\mathrm{NH}_{2}$, which is a common byproduct in Suzuki-Miyaura reactions. ${ }^{39}$ Biaryl cyclic tripeptide $\mathbf{1 3}$ was isolated by reverse-phase column chromatography and analyzed by HPLC and was obtained in $99 \%$ purity. It was also characterized by mass spectrometry and nuclear magnetic resonance (NMR) spectroscopy.

The strategy described for resin 4 was then applied to the synthesis of the biaryl cyclic peptidyl resin 5, bearing a TyrTyr linkage (Scheme 2). Accordingly, the tripeptidyl resin BocTyr(3-I,Me)-Ala-Tyr(3-BPin,Me)-Rink-MBHA (8), containing a 3-boronotyrosine and a 3-iodotyrosine, was prepared from Tr-Ala-Tyr(3-BPin,Me)-Rink-MBHA (12) by trityl group removal and coupling of $\operatorname{Boc}-\mathrm{Tyr}(3-\mathrm{I}, \mathrm{Me})-\mathrm{OH}^{30}$ mediated by DIPCDI and Oxyma in DMF. Acidolytic cleavage of an aliquot of 8 afforded H-Tyr(3-I,Me)-Ala-Tyr(3$\left.\mathrm{B}(\mathrm{OH})_{2}, \mathrm{Me}\right)-\mathrm{NH}_{2}$ in $82 \%$ purity, which was characterized by mass spectrometry. Resin $\mathbf{8}$ was then subjected to SuzukiMiyaura macrocyclization under the same conditions employed for the cyclization of resin 7. HPLC and mass spectrometry analysis of the crude reaction mixture from the cleavage of an aliquot of the resulting resin 5 revealed the formation of the expected biaryl cyclic tripeptide 14 in $73 \%$ purity. Similar to 13 , this biaryl cyclic peptide 14 was obtained together with traces of the protodeborylated byproduct $\mathrm{H}$ $\operatorname{Tyr}(3-\mathrm{I}, \mathrm{Me})$-Ala-Tyr(Me)- $\mathrm{NH}_{2}$. The biaryl cyclic peptide 14 was purified by column chromatography. It was obtained in $>99 \%$ HPLC purity and characterized by mass spectrometry and NMR spectroscopy.

Similarly, we attempted the synthesis of resins 6 bearing a His-Tyr linkage (Scheme 2). In this case, after trityl group removal of Tr-Ala-Tyr(3-BPin,Me)-Rink-MBHA (12), the regioisomeric mixture of Boc-His(5-Br,1-SEM)-OH and Boc$\mathrm{His}(5-\mathrm{Br}, 3-\mathrm{SEM})-\mathrm{OH}^{30}$ was coupled to the free amino group, affording resins Boc-His(5-Br,1-SEM)-Ala-Tyr(3-BPin,Me)Rink-MBHA (9a) and Boc-His(5-Br,3-SEM)-Ala-Tyr(3BPin,Me)-Rink-MBHA (9b). TFA/ $\mathrm{H}_{2} \mathrm{O} / \mathrm{TIS}$ treatment of an aliquot of 9 under stirring for $3 \mathrm{~h}$ yielded $\mathrm{H}-\mathrm{His}(5-\mathrm{Br})$-Ala$\operatorname{Tyr}\left(3-\mathrm{B}(\mathrm{OH})_{2}, \mathrm{Me}\right)-\mathrm{NH}_{2}$ in $82 \%$ purity, and it was characterized by mass spectrometry. Subsequent intramolecular Suzuki-Miyaura macrocyclization of resins 9 at $140{ }^{\circ} \mathrm{C}$ provided the expected regioisomeric biaryl cyclic tripeptidyl resins 6. An aliquot of these resins was cleaved and analyzed by HPLC and mass spectrometry. We observed the formation of the expected biaryl cyclic tripeptide $\mathbf{1 5}$ in $65 \%$ purity together with the protodeborylated $\mathrm{H}-\mathrm{His}(5-\mathrm{Br})-\mathrm{Ala}-\mathrm{Tyr}(\mathrm{Me})-\mathrm{NH}_{2}$ and oxidized $\mathrm{H}-\mathrm{His}(5-\mathrm{Br})-\mathrm{Ala}-\mathrm{Tyr}(3-\mathrm{OH}, \mathrm{Me})-\mathrm{NH}_{2}$ byproducts, with the latter also being a common side product from Suzuki-Miyaura cross-couplings. ${ }^{39}$ In agreement with previous reports, ${ }^{34,36}$ this result revealed that the macrocyclization through the formation of a His-Tyr linkage is more difficult than that involving a Phe-Tyr or a Tyr-Tyr bond. The biaryl cyclic tripeptide 15 was purified by column chromatography (75\% HPLC purity) and characterized by mass spectrometry and NMR spectroscopy. 
Scheme 4. Synthesis of Biaryl Cyclic Lipopeptides 31-33
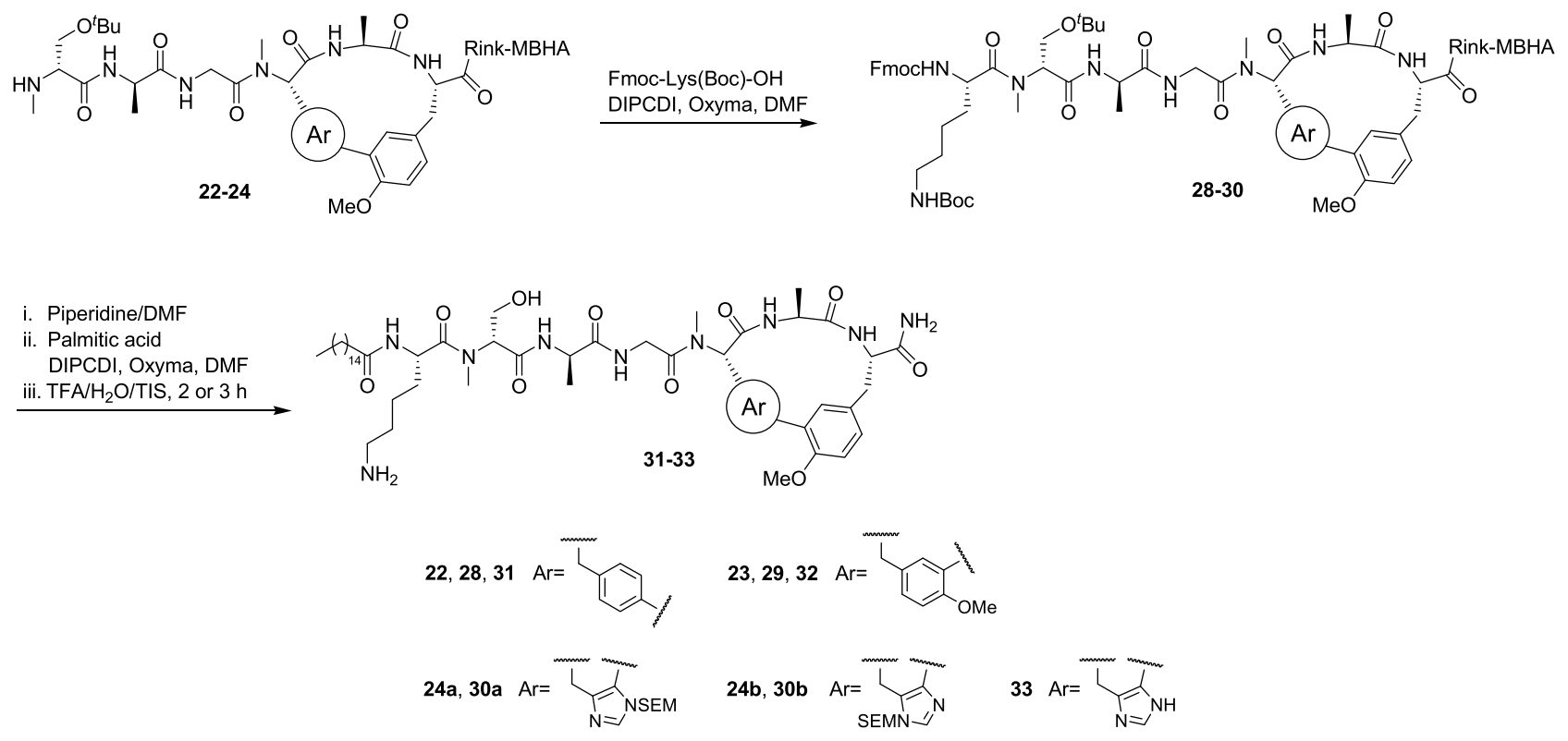

Synthesis of the Biaryl Cyclic Lipohexapeptides 1-3. With the peptidyl resins 4-6 in hand, we then proceeded to the N-methylation of the biaryl unit and the elongation of the lipopeptidyl tail to obtain the biaryl cyclic lipohexapeptides 13 (Scheme 3). For this purpose, the N-terminal Boc group of peptidyl resins 4-6 was selectively removed under mild conditions, using trimethylsilyl triflate (TMSOTf) in the presence of 2,6-lutidine in $\mathrm{CH}_{2} \mathrm{Cl}_{2}{ }^{40} \mathrm{~N}$-methylation was then performed following a three-step procedure that involved protection of the $\mathrm{N}$-terminal amine with an $o$-nitrobenzenesulfonyl (oNBS) group, followed by Mitsunobu N-methylation of the sulfonamide and $o$ NBS group removal. ${ }^{41-43}$ Protection of the free amino group was achieved with $o \mathrm{NBS}-\mathrm{Cl}$ and DIEA in $\mathrm{CH}_{2} \mathrm{Cl}_{2}$. Mitsunobu N-methylation required the use of $\mathrm{PPh}_{3}$ (25 equiv), $\mathrm{MeOH}$ (50 equiv), and diisopropyl azodicarboxylate (DIAD) (25 equiv) in anhydrous THF. The $o$ NBS group was easily removed with $\beta$-mercaptoethanol and 1,8 diazabicyclo[5.4.0] undec-7-ene (DBU) in DMF. This reaction was monitored by HPLC analysis of the crude reaction mixture from acidolytic cleavage of an aliquot of the resulting $\mathrm{N}$ methylated biaryl cyclic peptidyl resins 16-18. After two treatments of $15 \mathrm{~min}$, the expected $\mathrm{N}$-methylated biaryl cyclic peptides incorporating a Phe-Tyr, a Tyr-Tyr, or a His-Tyr linkage were obtained in 92, 89, and 32\% HPLC purity, respectively. These peptides were characterized by mass spectrometry.

The tripeptidyl tail was assembled at the $\mathrm{N}$-terminus of resins $16-18$ by sequential coupling of the corresponding Fmoc-protected amino acid and deprotection steps following the standard Fmoc/tBu strategy (Scheme 3). Fmoc-Gly-OH, Fmoc-D-Ala-OH, and Fmoc-D-Ser $(t \mathrm{Bu})-\mathrm{OH}$ were employed as Fmoc amino acids and were incorporated into the resin using DIPCDI and Oxyma in DMF. The completion of the couplings onto primary and secondary amines was monitored with the ninhydrin and chloranil tests, respectively. ${ }^{44,45}$ An aliquot of the resulting tailed biaryl cyclic peptidyl resins 1921 was cleaved under acidolytic conditions, providing the corresponding biaryl cyclic hexapeptides bearing a Phe-Tyr, a Tyr-Tyr, and a His-Tyr linkage in 85,75 , and $18 \%$ HPLC purity, respectively, which were characterized by mass spectrometry.

Finally, the N-methylation of the peptidyl resins 19-21 was achieved following the three-step procedure described for the preparation of resins $\mathbf{1 6 - 1 8}$ (Scheme 3). Thus, oNBS protection, Mitsunobu N-methylation, and oNBS group removal afforded the tailed biaryl cyclic peptidyl resins 2224. Acidolytic cleavage of an aliquot of these resins and HPLC analysis revealed the formation of the expected biaryl cyclic peptides 25-27 in 84, 65, and 32\% purity, respectively. Peptides 25-27 were isolated by reverse-phase column chromatography in $>99,78$, and $50 \%$ HPLC purity, respectively. These compounds were characterized by mass spectrometry and peptide $\mathbf{2 5}$ also by NMR spectroscopy.

The final step for the preparation of biaryl cyclic lipopeptides 1-3 involved the acylation of the tailed biaryl cyclic peptidyl resins 22-24 with palmitic acid (Scheme 3). The acylation was carried out by treatment of the resin with palmitic acid, DIPCDI, and Oxyma in DMF overnight. The completion of the reaction was checked with the chloranil test. $^{45}$ The resulting biaryl cyclic lipopeptidyl resins were acidolytically cleaved, and the crude reaction mixtures were analyzed by HPLC and mass spectrometry. However, only traces of the expected palmitoylated sequences 1-3 were obtained, with the major product peptides being 25-27 without the palmitoyl group. Although different assays were performed, we were not able to improve the acylation of peptidyl resins 22-24.

Despite the above results, we decided to assay the incorporation of an amino acid at the N-terminus of the peptidyl tail of resins 22-24 instead of palmitic acid. A Lys residue was selected because it could favor the analysis of the biaryl cyclic lipopeptides by mass spectrometry (Scheme 4). Thus, Fmoc-Lys(Boc)-OH was coupled to the N-terminus of these resins using DIPCDI and Oxyma in DMF, leading to resins 28-30. After Fmoc group removal, they were acylated with palmitic acid as described above. Acidolytic cleavage provided the biaryl cyclic lipopeptides $31-33$ in $34-69 \%$ purity. As expected, the electrospray ionization-mass spectrometry (ESI-MS) and the high-resolution mass spectroscopy 
(HRMS) of these compounds showed a strong peak corresponding to $[\mathrm{M}+\mathrm{H}]^{+}$. Compounds 31-33 were purified by column chromatography and obtained in $87-97 \%$ HPLC purity. Biaryl cyclic peptides 31 and 32 were also fully characterized by NMR spectroscopy. These results demonstrated that the presence of an amino acid at the $\mathrm{N}$-methylated tail of these compounds facilitates the incorporation of the palmitic acid.

\section{CONCLUSIONS}

The first total solid-phase synthesis of arylomycin derivatives incorporating a Phe-Tyr, a Tyr-Tyr, or a His-Tyr biaryl linkage is reported. The biaryl cyclic cores were synthesized on solid support through Miyaura borylation of a 3-iodotyrosinecontaining peptidyl resin, subsequent coupling of the corresponding haloamino acid, and final cyclization via an intramolecular Suzuki-Miyaura cross-coupling reaction. The lipopeptidyl tail was assembled through $\mathrm{N}$-methylation, coupling of the corresponding amino acids, and acylation. The characterization of the arylomycin derivatives containing an extra lysine at the lipopeptidyl tail confirmed the effectiveness of our strategy. In this synthetic approach, all steps are performed on the solid phase, including the preparation of the boronotyrosine and the Suzuki-Miyaura reaction. Thus, it not only offers the advantages of the solid phase but can also allow the synthesis of other biarylcontaining natural products as well as the preparation of collections of synthetic arylomycin analogues and, therefore, the identification of new bioactive compounds.

\section{EXPERIMENTAL SECTION}

General Methods. Manual peptide synthesis was performed in polypropylene syringes $(2$ or $5 \mathrm{~mL}$ ) fitted with a polyethylene porous disk. Solvents and soluble reagents were removed by suction. Most chemicals were purchased from commercial suppliers Merck (Madrid, Spain), Iris Biotech GmbH (Marktredwitz, Germany), Scharlab (Sentmenat, Spain), or Panreac (Castellar del Vallès, Spain) and used without further purification.

Peptides were analyzed under standard analytical HPLC conditions with a Dionex liquid chromatography instrument composed of a UV/Vis Dionex UVD170U detector, a P680 Dionex bomb, an ASI-100 Dionex automatic injector, and CHROMELEON 6.60 software. Detection was performed at a wavelength of $220 \mathrm{~nm}$. Solvent A was $0.1 \%$ aqueous TFA, and solvent $\mathrm{B}$ was $0.1 \%$ TFA in $\mathrm{CH}_{3} \mathrm{CN}$. Conditions A: Analysis was carried out with a Kromasil $100 \mathrm{C}_{18}(4.6 \mathrm{~mm} \times 40 \mathrm{~mm}$, $3.5 \mu \mathrm{m}$ ) column with a $2-100 \% \mathrm{~B}$ over $7 \mathrm{~min}$ at a flow rate of $1 \mathrm{~mL} / \mathrm{min}$. Conditions B: Analysis was carried out with a Kromasil $100 \mathrm{C}_{18}(4.6 \mathrm{~mm} \times 250 \mathrm{~mm}, 5 \mu \mathrm{m})$ column with a $2-100 \%$ B over $28 \mathrm{~min}$ at a flow rate of $1 \mathrm{~mL} / \mathrm{min}$.

All purifications were performed on a CombiFlash Rf200 automated flash chromatography system using RediSep $\mathrm{Rf}$ Gold reversed-phase $\mathrm{C}_{18}$ column packed with high-performance $\mathrm{C}_{18}$ derivatized silica.

ESI-MS analyses were performed at the Serveis Tècnics de Recerca of the University of Girona with an Esquire 6000 ESI ion trap LC/MS (Bruker Daltonics) instrument equipped with an electrospray ion source. The instrument was operated in the positive $\operatorname{ESI}(+)$ ion mode. Samples $(5 \mu \mathrm{L})$ were introduced into the mass spectrometer ion source directly through an HPLC autosampler. The mobile phase $\left(80: 20 \mathrm{CH}_{3} \mathrm{CN} / \mathrm{H}_{2} \mathrm{O}\right.$ at a flow rate of $100 \mu \mathrm{L} / \mathrm{min}$ ) was delivered by a 1200 Series HPLC pump (Agilent). Nitrogen was employed as both the drying and nebulizing gas.

HRMS was performed on a Bruker MicroTof-QIITM instrument using an ESI ionization source at the Serveis Tècnics de Recerca of the University of Girona. Samples were introduced into the mass spectrometer ion source by direct infusion using a syringe pump and were externally calibrated using sodium formate. The instrument was operated in the positive ion mode.

${ }^{1} \mathrm{H}$ and ${ }^{13} \mathrm{C}$ NMR spectra were recorded with a Bruker 300 or $400 \mathrm{MHz}$ NMR spectrometer at the Serveis Tècnics de Recerca of the University of Girona. Chemical shifts were reported as $\delta$ values (ppm) directly referenced to the solvent signal.

Microwave-assisted reactions were performed with a singlemode Discover S-Class lab station microwave (CEM) (0-300 $\mathrm{W})$. The time, temperature, and power were controlled with the Synergy software. The temperature was monitored through an infrared sensor in the floor of the cavity.

Synthesis of Tr-Ala-Tyr(3-I,Me)-Rink-MBHA (11). Fmoc-Rink-MBHA resin $(0.4 \mathrm{mmol} / \mathrm{g})$ was placed in a polypropylene syringe fitted with a polyethylene filter disk and swollen with $\mathrm{CH}_{2} \mathrm{Cl}_{2}(1 \times 20 \mathrm{~min})$ and DMF $(1 \times 20$ $\mathrm{min})$, treated with piperidine/DMF $(3: 7,1 \times 5 \mathrm{~min})$, and washed with DMF $(6 \times 1 \mathrm{~min})$. Then, removal of the Fmoc protecting group was achieved with a mixture of piperidine/ DMF $(3: 7,2+10 \mathrm{~min})$, followed by washes with DMF $(6 \times 1$ min). Fmoc-Tyr(3-I,Me)- $\mathrm{OH}^{36}$ (2 equiv) was coupled in the presence of COMU ( 2 equiv), Oxyma ( 2 equiv), and DIEA (4 equiv) in DMF under stirring at room temperature overnight. The completion of the reaction was monitored by the Kaiser test. ${ }^{44}$ The resin was then washed with DMF $(6 \times 1 \mathrm{~min})$ and $\mathrm{CH}_{2} \mathrm{Cl}_{2}(3 \times 1 \mathrm{~min})$. After Fmoc removal as described above, coupling of commercially available Fmoc-Ala-OH (4 equiv) was performed using DIPCDI (4 equiv) and Oxyma (4 equiv) in DMF at room temperature for $1 \mathrm{~h}$, followed by washes with DMF $(6 \times 1 \mathrm{~min})$ and $\mathrm{CH}_{2} \mathrm{Cl}_{2}(3 \times 1 \mathrm{~min})$. The completion of the reaction was monitored by the Kaiser test. ${ }^{44}$ An aliquot of the resulting Fmoc-protected iodopeptidyl resin 10 was cleaved with TFA/ $\mathrm{H}_{2} \mathrm{O} / \mathrm{TIS}$ (95:2.5:2.5) while stirring at room temperature for $2 \mathrm{~h}$. Following TFA evaporation and diethyl ether extraction, the crude peptide was dissolved in $\mathrm{H}_{2} \mathrm{O} / \mathrm{CH}_{3} \mathrm{CN}$ (1:1) and lyophilized to give Fmoc-Ala-Tyr(3$\mathrm{I}, \mathrm{Me}$ ) $-\mathrm{NH}_{2}$ in $98 \%$ purity. $t_{\mathrm{R}}=8.51 \mathrm{~min}$ (Conditions A).

Next, the $\mathrm{N}$-terminal Fmoc group of $\mathbf{1 0}$ was removed as described above, and a trityl group was introduced using $\mathrm{TrCl}$ (10 equiv) and DIEA (10 equiv) in DMF under stirring at room temperature for $4 \mathrm{~h}$. Then, the resin was washed with DMF $(6 \times 1 \mathrm{~min}), \mathrm{CH}_{2} \mathrm{Cl}_{2}(3 \times 1 \mathrm{~min})$, and diethyl ether $(3$ $\times 1 \mathrm{~min})$. The completion of this reaction was monitored with the Kaiser test. ${ }^{44}$ Acidolytic cleavage of an aliquot of the resulting iodopeptidyl resin 11 afforded $\mathrm{H}$-Ala-Tyr(3-I,Me)$\mathrm{NH}_{2}$ in $92 \%$ purity. $t_{\mathrm{R}}=6.10 \mathrm{~min}$ (Conditions A). MS (ESI): $m / z=392.0[\mathrm{M}+\mathrm{H}]^{+}, 414.0[\mathrm{M}+\mathrm{Na}]^{+}$.

Synthesis of Tr-Ala-Tyr(3-BPin,Me)-Rink-MBHA (12). A 5-10 mL round-bottomed flask was charged with the iodopeptidyl resin 11, bis(pinacolato)diboron $\left(\mathrm{B}_{2} \mathrm{Pin}_{2}\right)$ (4 equiv), $\mathrm{PdCl}_{2}$ (dppf) ( 0.18 equiv), and $1,1^{\prime}$-bis(diphenylphosphanyl)ferrocene (dppf) (0.09 equiv). A thoroughly sonicated solution of KOAc (6 equiv) in degassed anhydrous DMSO $(20 \mu \mathrm{L} / \mathrm{mg}$ of resin) was then added, and the mixture was heated at $80{ }^{\circ} \mathrm{C}$ for $8 \mathrm{~h}$. Upon completion of 
the reaction, the resin was washed with DMSO $(6 \times 1 \mathrm{~min})$, $\mathrm{MeOH}(6 \times 1 \mathrm{~min}), \mathrm{CH}_{2} \mathrm{Cl}_{2}(6 \times 1 \mathrm{~min})$, and diethyl ether $(3$ $\times 1 \mathrm{~min})$. An aliquot of the resulting boronopeptidyl resin 12 was cleaved with TFA $/ \mathrm{H}_{2} \mathrm{O} / \mathrm{TIS}$ (95:2.5:2.5) while stirring for $2 \mathrm{~h}$ at room temperature. Following TFA evaporation and diethyl ether extraction, the crude peptide was dissolved in $\mathrm{H}_{2} \mathrm{O} / \mathrm{CH}_{3} \mathrm{CN}$ (1:1), lyophilized, analyzed by HPLC, and characterized by mass spectrometry. H-Ala-Tyr(3-B$\left.(\mathrm{OH})_{2}, \mathrm{Me}\right)-\mathrm{NH}_{2}$ was obtained in $72 \%$ purity, which resulted from the hydrolysis of the pinacol boronic ester during HPLC analysis. $t_{\mathrm{R}}=13.79 \min$ (Conditions B). MS (ESI): $\mathrm{m} / z=$ $310.1[\mathrm{M}+\mathrm{H}]^{+}$, 332.1 $[\mathrm{M}+\mathrm{Na}]^{+}$.

General Procedure for the Synthesis of Tripeptidyl Resins 7-9. The boronopeptidyl resin 12 was swollen with $\mathrm{CH}_{2} \mathrm{Cl}_{2}(1 \times 20 \mathrm{~min})$; treated with $\mathrm{TFA} / \mathrm{H}_{2} \mathrm{O} / \mathrm{CH}_{2} \mathrm{Cl}_{2}$ $(0.2: 1: 98.8,2 \times 1 \mathrm{~min}+3 \times 20 \mathrm{~min})$; and washed with DMF $(3 \times 1 \mathrm{~min})$, DIEA/ $\mathrm{CH}_{2} \mathrm{Cl}_{2}(1: 19,3 \times 1 \mathrm{~min}), \mathrm{CH}_{2} \mathrm{Cl}_{2}$ $(3 \times 1 \mathrm{~min})$, and DMF $(3 \times 1 \mathrm{~min})$. Then, coupling of BocPhe(4-I)-OH, ${ }^{37}$ Boc-Tyr(3-I,Me $)-O H,{ }^{30}$ or a regioisomeric mixture of Boc-His(5-Br,1-SEM)-OH and Boc-His(5-Br,3SEM) $-\mathrm{OH}^{30}$ was carried out using DIPCDI (3 equiv) and Oxyma ( 3 equiv) in DMF at room temperature for $3 \mathrm{~h}$, followed by washes with DMF $(6 \times 1 \mathrm{~min}), \mathrm{CH}_{2} \mathrm{Cl}_{2}(3 \times 1$ $\mathrm{min})$, and diethyl ether $(3 \times 1 \mathrm{~min})$. An aliquot of the resulting resin was cleaved with TFA/ $\mathrm{H}_{2} \mathrm{O} / \mathrm{TIS}$ (95:2.5:2.5) while stirring for 2 or $3 \mathrm{~h}$ at room temperature. Following TFA evaporation and diethyl ether extraction, the crude peptide was dissolved in $\mathrm{H}_{2} \mathrm{O} / \mathrm{CH}_{3} \mathrm{CN}$ (1:1), lyophilized, analyzed by HPLC, and characterized by mass spectrometry.

Synthesis of Boc-Phe(4-I)-Ala-Tyr(3-BPin,Me)-Rink-MBHA (7). This peptidyl resin was prepared using the procedure described above, employing Boc-Phe(4-I)-OH. ${ }^{37}$ Acidolytic cleavage of the resulting resin 7 for $2 \mathrm{~h}$ afforded $\mathrm{H}$-Phe(4-I)Ala- $\operatorname{Tyr}\left(3-\mathrm{B}(\mathrm{OH})_{2}, \mathrm{Me}\right)-\mathrm{NH}_{2}$ in $81 \%$ purity, resulting from the hydrolysis of the pinacol boronic ester during HPLC analysis. $t_{\mathrm{R}}=18.03 \mathrm{~min}$ (Conditions B). MS (ESI): $m / z=583.1[\mathrm{M}+$ $\mathrm{H}]^{+}$.

Synthesis of Boc-Tyr(3-I,Me)-Ala-Tyr(3-BPin,Me)-Rink$M B H A$ (8). This peptidyl resin was prepared using the procedure described above, employing Boc-Tyr(3-I,Me)$\mathrm{OH}^{30}$ Acidolytic cleavage of the resulting resin 8 for $2 \mathrm{~h}$ afforded H-Tyr(3-I,Me)-Ala- $\mathrm{Tyr}\left(3-\mathrm{B}(\mathrm{OH})_{2}, \mathrm{Me}\right)-\mathrm{NH}_{2}$ in $82 \%$ purity, resulting from the hydrolysis of the pinacol boronic ester during HPLC analysis. $t_{\mathrm{R}}=17.99 \mathrm{~min}$ (Conditions B). MS (ESI): $m / z=613.1[\mathrm{M}+\mathrm{H}]^{+}, 635.1[\mathrm{M}+\mathrm{Na}]^{+}$.

Synthesis of Boc-His(5-Br,1-SEM)-Ala-Tyr(3-BPin,Me)Rink-MBHA (9a) and Boc-His(5-Br,3-SEM)-Ala-Tyr(3BPin,Me)-Rink-MBHA (9b). These peptidyl resins were prepared using the procedure described above, employing a regioisomeric mixture of Boc-His(5-Br,1-SEM)-OH and Boc$\mathrm{His}(5-\mathrm{Br}, 3-\mathrm{SEM})-\mathrm{OH}^{30}$ Acidolytic cleavage of the resulting resins 9 for $3 \mathrm{~h}$ afforded $\mathrm{H}-\mathrm{His}(5-\mathrm{Br})-\mathrm{Ala}-\mathrm{Tyr}\left(3-\mathrm{B}(\mathrm{OH})_{2}, \mathrm{Me}\right)-$ $\mathrm{NH}_{2}$ in $82 \%$ purity, resulting from the hydrolysis of the pinacol boronic ester during HPLC analysis. $t_{\mathrm{R}}=14.20 \mathrm{~min}$ (Conditions B). MS (ESI): $m / z=525.1,527.1[\mathrm{M}+\mathrm{H}]^{+}$, 547.1, $549.1[\mathrm{M}+\mathrm{Na}]^{+}$.

Synthesis of the Biaryl Cyclic Tripeptidyl Resins 4-6. General Method for the Microwave-Assisted Solid-Phase Intramolecular Suzuki-Miyaura Arylation. A $15 \mathrm{~mL}$ reaction vessel containing a magnetic stir bar was charged with the corresponding linear peptidyl resin 7-9 (100 mg), $\mathrm{Pd}_{2}(\mathrm{dba})_{3}$ ( 0.2 equiv), SPhos ( 0.4 equiv), and KF (4 equiv). Thoroughly degassed $\mathrm{DME} / \mathrm{EtOH} / \mathrm{H}_{2} \mathrm{O}(9: 9: 2,0.8 \mathrm{~mL})$ was then added under nitrogen. The reaction mixture was heated under microwave irradiation at 120 or $140{ }^{\circ} \mathrm{C}$ for $30 \mathrm{~min}$. Then, upon cooling, the solvent was removed by filtration and the resin was washed with DMF $(6 \times 1 \mathrm{~min}), \mathrm{EtOH}(6 \times 1 \mathrm{~min})$, $\mathrm{CH}_{2} \mathrm{Cl}_{2}(6 \times 1 \mathrm{~min})$, and diethyl ether $(3 \times 1 \mathrm{~min})$. A solution of TFA $/ \mathrm{H}_{2} \mathrm{O} / \mathrm{TIS}$ (95:2.5:2.5) was then added to an aliquot of the resulting resin, and the mixture was stirred at room temperature for 2 or $3 \mathrm{~h}$. TFA evaporation and diethyl ether extraction gave the corresponding crude peptide mixture, which was dissolved in $\mathrm{H}_{2} \mathrm{O} / \mathrm{CH}_{3} \mathrm{CN}$ (1:1), lyophilized, analyzed by HPLC, characterized by mass spectrometry, and purified by reverse-phase column chromatography. Pure biaryl cyclic tripeptides were analyzed by HPLC, and characterized by mass spectrometry and NMR spectroscopy.

Biaryl Cyclic Tripeptidyl Resin 4. This biaryl cyclic tripeptidyl resin was prepared from the linear peptidyl resin Boc-Phe(4-I)-Ala-Tyr(3-BPin,Me)-Rink-MBHA (7) following the procedure described above at $120^{\circ} \mathrm{C}$. Acidolytic cleavage of an aliquot of the resulting resin 4 for $2 \mathrm{~h}$ afforded the biaryl cyclic tripeptide 13 in $92 \%$ purity. $t_{\mathrm{R}}=16.75 \mathrm{~min}$ (Conditions B). MS (ESI): $m / z=411.1[\mathrm{M}+\mathrm{H}]^{+}$. Reverse-phase column chromatography and elution with $\mathrm{H}_{2} \mathrm{O} / \mathrm{CH}_{3} \mathrm{CN}$ (80:20) afforded the expected biaryl cyclic tripeptide 13 in $99 \%$ purity. $t_{\mathrm{R}}=6.20 \mathrm{~min}$ (Conditions A). ${ }^{1} \mathrm{H}$ NMR $\left(400 \mathrm{MHz}, \mathrm{CD}_{3} \mathrm{OD}\right)$ : $\delta=7.41\left[\mathrm{dd}, J=1.6\right.$ and $\left.8.0 \mathrm{~Hz}, 1 \mathrm{H}, \mathrm{CH}_{\text {arom }} \mathrm{Phe}\right], 7.34[\mathrm{dd}, J=$ 1.6 and $\left.8.0 \mathrm{~Hz}, 1 \mathrm{H}, \mathrm{CH}_{\text {arom }} \mathrm{Phe}\right], 7.22[\mathrm{dd}, J=1.6$ and $8.0 \mathrm{~Hz}$, $\left.1 \mathrm{H}, \mathrm{CH}_{\text {arom }} \mathrm{Phe}\right], 7.12-7.08\left[\mathrm{~m}, 2 \mathrm{H}, \mathrm{CH}_{\text {arom }} \mathrm{Phe}, \mathrm{CH}-\right.$ $\left.6_{\text {arom }} \mathrm{Tyr}\right], 6.97\left[\mathrm{~d}, J=8.4 \mathrm{~Hz}, 1 \mathrm{H}, \mathrm{CH}-5_{\text {arom }} \mathrm{Tyr}\right], 6.81[\mathrm{~d}, J$ $\left.=2.4 \mathrm{~Hz}, 1 \mathrm{H}, \mathrm{CH}-2_{\text {arom }} \mathrm{Tyr}\right], 4.31[\mathrm{dd}, J=4.0$ and $9.2 \mathrm{~Hz}, 1 \mathrm{H}$, $\mathrm{CH}-\alpha], 4.01[\mathrm{q}, J=6.6 \mathrm{~Hz}, 1 \mathrm{H}, \mathrm{CH}-\alpha \mathrm{Ala}], 3.90-3.86[\mathrm{~m}, 1 \mathrm{H}$, $\mathrm{CH}-\alpha], 3.86\left[\mathrm{~s}, 3 \mathrm{H}, \mathrm{OCH}_{3}\right], 3.52-3.42[\mathrm{~m}, 1 \mathrm{H}, \mathrm{CH}-\beta], 2.92-$ $2.82[\mathrm{~m}, 3 \mathrm{H}, \mathrm{CH}-\beta], 1.26\left[\mathrm{~d}, J=6.6 \mathrm{~Hz}, 3 \mathrm{H}, \mathrm{CH}_{3}-\mathrm{Ala}\right] \mathrm{ppm}$. MS (ESI): $m / z=411.1[\mathrm{M}+\mathrm{H}]^{+}$. HRMS (ESI): calcd for $\mathrm{C}_{22} \mathrm{H}_{27} \mathrm{~N}_{4} \mathrm{O}_{4}[\mathrm{M}+\mathrm{H}]^{+}$411.2027, found 411.2036; calcd for $\mathrm{C}_{22} \mathrm{H}_{26} \mathrm{~N}_{4} \mathrm{O}_{4} \mathrm{Na}[\mathrm{M}+\mathrm{Na}]^{+}$433.1846, found 433.1852.

Biaryl Cyclic Tripeptidyl Resin 5. This biaryl cyclic tripeptidyl resin was prepared from the linear peptidyl resin Boc-Tyr(3-I,Me)-Ala-Tyr(3-BPin,Me)-Rink-MBHA (8) following the procedure described above at $120{ }^{\circ} \mathrm{C}$. Acidolytic cleavage of an aliquot of the resulting resin 5 for $2 \mathrm{~h}$ afforded the biaryl cyclic tripeptide 14 in $73 \%$ purity. $t_{\mathrm{R}}=15.97 \mathrm{~min}$ (Conditions B). MS (ESI): $m / z=441.2[\mathrm{M}+\mathrm{H}]^{+}$. Reversephase column chromatography and elution with $\mathrm{H}_{2} \mathrm{O} / \mathrm{CH}_{3} \mathrm{CN}$ (85:15) afforded the expected biaryl cyclic tripeptide 14 in $>99 \%$ purity. $t_{\mathrm{R}}=5.98 \mathrm{~min}$ (Conditions A). ${ }^{1} \mathrm{H}$ NMR (400 $\left.\mathrm{MHz}, \mathrm{CD}_{3} \mathrm{OD}\right): \delta=7.21[\mathrm{dd}, J=2.2$ and $8.4 \mathrm{~Hz}, 1 \mathrm{H}, \mathrm{CH}-$ $6^{\prime}{ }_{\text {arom }} \mathrm{Tyr}$ ], 7.14 [dd, $J=2.2$ and $8.4 \mathrm{~Hz}, 1 \mathrm{H}, \mathrm{CH}-6_{\text {arom }} \mathrm{Tyr}$ ], $7.05\left[\mathrm{~d}, J=2.2 \mathrm{~Hz}, 1 \mathrm{H}, \mathrm{CH}-2^{\prime}{ }_{\text {arom }} \mathrm{Tyr}\right], 6.96[\mathrm{~d}, J=8.4 \mathrm{~Hz}$, $\left.1 \mathrm{H}, \mathrm{CH}-5_{\text {arom }} \mathrm{Tyr}\right], 6.90\left[\mathrm{~d}, J=8.4 \mathrm{~Hz}, 1 \mathrm{H}, \mathrm{CH}-5^{\prime}{ }_{\text {arom }} \mathrm{Tyr}\right.$, $6.84\left[\mathrm{~d}, J=2.2 \mathrm{~Hz}, 1 \mathrm{H}, \mathrm{CH}-2_{\text {arom }} \mathrm{Tyr}\right], 6.68[\mathrm{~d}, J=2.0 \mathrm{~Hz}, 1 \mathrm{H}$, $\mathrm{NH}], 6.62[\mathrm{~d}, J=2.0 \mathrm{~Hz}, 1 \mathrm{H}, \mathrm{NH}], 4.80-4.75[\mathrm{~m}, 1 \mathrm{H}, \mathrm{CH}-$ $\alpha \mathrm{Ala}], 4.63-4.45[\mathrm{~m}, 1 \mathrm{H}, \mathrm{CH}-\alpha], 4.22[\mathrm{dd}, J=3.6$ and $4.0 \mathrm{~Hz}$, $1 \mathrm{H}, \mathrm{CH}-\alpha], 3.77\left[\mathrm{~s}, 3 \mathrm{H}, \mathrm{OCH}_{3}\right], 3.72\left[\mathrm{~s}, 3 \mathrm{H}, \mathrm{OCH}_{3}\right], 3.39$ $[\mathrm{dd}, J=3.6$ and $15.0 \mathrm{~Hz}, 1 \mathrm{H}, \mathrm{CH}-\beta], 3.05[\mathrm{dd}, J=4.0$ and 15.0 $\mathrm{Hz}, 1 \mathrm{H}, \mathrm{CH}-\beta], 2.97-2.83[\mathrm{~m}, 2 \mathrm{H}, \mathrm{CH}-\beta], 1.39[\mathrm{~d}, J=6.8 \mathrm{~Hz}$, $3 \mathrm{H}, \mathrm{CH}_{3}$-Ala $]$ ppm. MS (ESI): $m / z=441.2[\mathrm{M}+\mathrm{H}]^{+}, 463.1$ $[\mathrm{M}+\mathrm{Na}]^{+}$. HRMS (ESI): calcd for $\mathrm{C}_{23} \mathrm{H}_{29} \mathrm{~N}_{4} \mathrm{O}_{5}[\mathrm{M}+\mathrm{H}]^{+}$ 441.2132, found 441.2132; calcd for $\mathrm{C}_{23} \mathrm{H}_{28} \mathrm{~N}_{4} \mathrm{O}_{5} \mathrm{Na}[\mathrm{M}+$ $\mathrm{Na}]^{+}$463.1952, found 463.1951.

Biaryl Cyclic Tripeptidyl Resins 6. These biaryl cyclic tripeptidyl resins were prepared from the regioisomeric linear peptidyl resins Boc-His(5-Br,1-SEM)-Ala-Tyr(3-BPin,Me)Rink-MBHA (9a) and Boc-His(5-Br,3-SEM)-Ala-Tyr(3- 
BPin,Me)-Rink-MBHA (9b) following the procedure described above at $140{ }^{\circ} \mathrm{C}$. Acidolytic cleavage of an aliquot of the resulting resins 6 for $3 \mathrm{~h}$ afforded the biaryl cyclic tripeptide 15 in $65 \%$ purity. $t_{\mathrm{R}}=12.64 \mathrm{~min}$ (Conditions B). MS (ESI): $m / z=401.2[\mathrm{M}+\mathrm{H}]^{+}$. Reverse-phase column chromatography and elution with $\mathrm{H}_{2} \mathrm{O} / \mathrm{CH}_{3} \mathrm{CN}$ (98:2) afforded the expected biaryl cyclic tripeptide 15 in $75 \%$ purity. $t_{\mathrm{R}}=4.79 \mathrm{~min}$ (Conditions A). ${ }^{1} \mathrm{H}$ NMR $\left(400 \mathrm{MHz}, \mathrm{CD}_{3} \mathrm{OD}\right)$ : $\delta=8.56\left[\mathrm{~s}, 1 \mathrm{H}, \mathrm{CH}_{\text {arom }} \mathrm{His}\right], 8.22[\mathrm{~d}, J=9.6 \mathrm{~Hz}, 1 \mathrm{H}, \mathrm{NH}]$, $7.40\left[\mathrm{dd}, J=2.0\right.$ and $\left.8.6 \mathrm{~Hz}, 1 \mathrm{H}, \mathrm{CH}-6_{\text {arom }} \mathrm{Tyr}\right], 7.07[\mathrm{~d}, J=$ $\left.8.6 \mathrm{~Hz}, 1 \mathrm{H}, \mathrm{CH}-5_{\text {arom }} \mathrm{Tyr}\right], 6.99[\mathrm{~d}, J=2.0 \mathrm{~Hz}, 1 \mathrm{H}, \mathrm{CH}-$ $2_{\text {arom }}$ Tyr $], 4.71-4.65[\mathrm{~m}, 1 \mathrm{H}, \mathrm{CH}-\alpha], 4.36[\mathrm{q}, J=7.0 \mathrm{~Hz}, 1 \mathrm{H}$, $\mathrm{CH}-\alpha \mathrm{Ala}], 4.09-4.07[\mathrm{~m}, 1 \mathrm{H}, \mathrm{CH}-\alpha], 3.81\left[\mathrm{~s}, 3 \mathrm{H}, \mathrm{OCH}_{3}\right]$, $3.42-3.31[\mathrm{~m}, 1 \mathrm{H}, \mathrm{CH}-\beta], 3.22-3.18[\mathrm{~m}, 2 \mathrm{H}, \mathrm{CH}-\beta], 2.71$ [dd, $J=11.6$ and $14.0 \mathrm{~Hz}, 1 \mathrm{H}, \mathrm{CH}-\beta], 1.20[\mathrm{~d}, J=7.0 \mathrm{~Hz}, 3 \mathrm{H}$, $\mathrm{CH}_{3}$-Ala $]$ ppm. MS (ESI): $m / z=401.1[\mathrm{M}+\mathrm{H}]^{+}$. HRMS (ESI): calcd for $\mathrm{C}_{19} \mathrm{H}_{25} \mathrm{~N}_{6} \mathrm{O}_{4}[\mathrm{M}+\mathrm{H}]^{+}$401.1932, found 401.1911.

Synthesis of the N-Methylated Biaryl Cyclic Tripeptidyl Resins 16-18. General Procedure for the NMethylation under Mitsunobu Conditions. The N-terminal Boc group of the corresponding biaryl cyclic tripeptidyl resin 4-6 was removed by treatment with a solution of TMSOTf and 2,6-lutidine in $\mathrm{CH}_{2} \mathrm{Cl}_{2}$ (final concentrations: $2 \mathrm{M}$ TMSOTf and $3 \mathrm{M}$ 2,6-lutidine $)(10 \times 30 \mathrm{~min})$ at room temperature, and the resulting resin was washed with $\mathrm{CH}_{2} \mathrm{Cl}_{2}$ $(5 \times 1 \mathrm{~min}), \mathrm{MeOH}(3 \times 5 \mathrm{~min})$, and DMF $(5 \times 1 \mathrm{~min}) . \mathrm{A}$ solution of $o \mathrm{NBS}-\mathrm{Cl}$ ( 4 equiv) and DIEA (10 equiv) in $\mathrm{CH}_{2} \mathrm{Cl}_{2}$ was then added to the resin, and the mixture was shaken for $90 \mathrm{~min}$ at room temperature. The resulting $o$ NBSprotected peptidyl resin was washed with DMF $(3 \times 0.5 \mathrm{~min})$, $\mathrm{CH}_{2} \mathrm{Cl}_{2}(3 \times 0.5 \mathrm{~min})$, and diethyl ether $(3 \times 1 \mathrm{~min})$. An aliquot of this peptidyl resin was cleaved with TFA/ $\mathrm{H}_{2} \mathrm{O} / \mathrm{TIS}$ (95:2.5:2.5) for 2 or $3 \mathrm{~h}$, and the crude was analyzed by HPLC and mass spectrometry.

Next, the oNBS-protected resin was N-methylated by treatment with a solution of $\mathrm{PPh}_{3}$ (25 equiv) and $\mathrm{MeOH}$ ( 50 equiv) in dry THF, followed by the addition of DIAD ( 25 equiv) in dry THF. The reaction mixture was stirred at room temperature for $1 \mathrm{~h}$. Then, the solution was filtered and the resulting resin was washed with THF $(3 \times 0.5 \mathrm{~min}), \mathrm{CH}_{2} \mathrm{Cl}_{2}$ $(3 \times 0.5 \mathrm{~min}), \mathrm{DMF}(3 \times 0.5 \mathrm{~min})$, and diethyl ether $(3 \times 1$ $\mathrm{min})$. The resulting resin was cleaved for 2 or $3 \mathrm{~h}$, analyzed by HPLC, and characterized by mass spectrometry.

Finally, the oNBS group was selectively removed by treatment with $\beta$-mercaptoethanol (10 equiv) and DBU (5 equiv) in DMF $(2 \times 15 \mathrm{~min})$ at room temperature under stirring, followed by washes with DMF $(3 \times 0.5 \mathrm{~min}), \mathrm{CH}_{2} \mathrm{Cl}_{2}$ $(3 \times 0.5 \mathrm{~min}), \mathrm{DMF}(3 \times 0.5 \mathrm{~min}), \mathrm{CH}_{2} \mathrm{Cl}_{2}(3 \times 0.5 \mathrm{~min})$, and diethyl ether $(3 \times 0.5 \mathrm{~min})$. Acidolytic cleavage of an aliquot of the resulting $\mathrm{N}$-methylated resin for 2 or $3 \mathrm{~h}$ afforded the expected $\mathrm{N}$-methylated biaryl cyclic tripeptide, which was analyzed by HPLC and characterized by mass spectrometry.

N-Methylated Biaryl Cyclic Tripeptidyl Resin 16. NMethylated cyclic peptidyl resin 16 was prepared from biaryl cyclic tripeptidyl resin 4 following the general procedure described above. $o$ NBS protection: acidolytic cleavage for $2 \mathrm{~h}$ of an aliquot of the resulting resin yielded the expected peptide in $69 \%$ purity. $t_{\mathrm{R}}=7.21 \mathrm{~min}$ (Conditions A). Mitsunobu Nmethylation: acidolytic cleavage for $2 \mathrm{~h}$ of an aliquot of the resulting resin yielded the expected peptide in $96 \%$ purity. $t_{\mathrm{R}}=$ $7.84 \mathrm{~min}$ (Conditions A). MS (ESI): $m / z=610.2[\mathrm{M}+\mathrm{H}]^{+}$,
$632.1[\mathrm{M}+\mathrm{Na}]^{+}$. oNBS group removal: acidolytic cleavage for $2 \mathrm{~h}$ of an aliquot of the resulting resin $\mathbf{1 6}$ yielded the expected $\mathrm{N}$-methylated biaryl cyclic tripeptide in $92 \%$ purity. $t_{\mathrm{R}}=6.12$ min (Conditions A). MS (ESI): $m / z=425.2[\mathrm{M}+\mathrm{H}]^{+}$.

N-Methylated Biaryl Cyclic Tripeptidyl Resin 17. Nmethylated cyclic peptidyl resin 17 was prepared from biaryl cyclic tripeptidyl resin $\mathbf{5}$ following the general procedure described above. $o$ NBS protection: acidolytic cleavage for $2 \mathrm{~h}$ of an aliquot of the resulting resin yielded the expected peptide in $46 \%$ purity. $t_{\mathrm{R}}=7.52 \mathrm{~min}$ (Conditions A). MS (ESI): $m / z=$ $626.2[\mathrm{M}+\mathrm{H}]^{+}, 648.1[\mathrm{M}+\mathrm{Na}]^{+}$. Mitsunobu N-methylation: acidolytic cleavage for $2 \mathrm{~h}$ of an aliquot of the resulting resin yielded the expected peptide in $60 \%$ purity. $t_{\mathrm{R}}=7.72 \mathrm{~min}$ (Conditions A). MS (ESI): $m / z=640.2[\mathrm{M}+\mathrm{H}]^{+}, 662.2[\mathrm{M}$ $+\mathrm{Na}]^{+}$. oNBS group removal: acidolytic cleavage for $2 \mathrm{~h}$ of an aliquot of the resulting resin 17 yielded the expected $\mathrm{N}$ methylated biaryl cyclic tripeptide in $89 \%$ purity. $t_{\mathrm{R}}=5.85 \mathrm{~min}$ (Conditions A). MS (ESI): $m / z=455.2[\mathrm{M}+\mathrm{H}]^{+}$.

N-Methylated Regioisomeric Biaryl Cyclic Tripeptidyl Resins 18. N-methylated regioisomeric cyclic peptidyl resins 18 were prepared from the regioisomeric biaryl cyclic tripeptidyl resins 6 following the general procedure described above. oNBS protection: acidolytic cleavage for $3 \mathrm{~h}$ of an aliquot of the resulting resins afforded the expected peptide in $53 \%$ purity. $t_{\mathrm{R}}=6.23 \mathrm{~min}$ (Conditions A). MS (ESI): $\mathrm{m} / z=$ 586.2 $[\mathrm{M}+\mathrm{H}]^{+}$. Mitsunobu N-methylation: acidolytic cleavage for $3 \mathrm{~h}$ of an aliquot of the resulting resins afforded the expected peptide in $40 \%$ purity. $t_{\mathrm{R}}=6.48 \mathrm{~min}$ (Conditions A). MS (ESI): $m / z=600.2[\mathrm{M}+\mathrm{H}]^{+}$. oNBS group removal: acidolytic cleavage for $3 \mathrm{~h}$ of an aliquot of the resulting peptidyl resins 18 afforded the expected $\mathrm{N}$-methylated biaryl cyclic tripeptide in $32 \%$ purity. $t_{\mathrm{R}}=4.89 \mathrm{~min}$ (Conditions $\mathrm{A}$ ). MS (ESI): $m / z=415.2[\mathrm{M}+\mathrm{H}]^{+}$.

Synthesis of Tailed Biaryl Cyclic Hexapeptidyl Resins 19-21. General Method for the Solid-Phase Peptide Elongation of N-Methylated Biaryl Cyclic Tripeptidyl Resins. These peptidyl resins were prepared from resins 16-18 through sequential coupling of the corresponding Fmoc amino acids and Fmoc removal steps. Couplings of Fmoc-Gly-OH, Fmoc-D-Ala-OH, and Fmoc-D-Ser $(t \mathrm{Bu})-\mathrm{OH}$ (4 equiv) were mediated by DIPCDI (4 equiv) and Oxyma (4 equiv) in DMF overnight at room temperature. The completion of the couplings was monitored using the Kaiser or the chloranil tests. $^{44,45}$ After coupling of Fmoc-Gly-OH, the Fmoc group was removed with piperidine/DMF $(3: 7,2+10+10 \mathrm{~min})$, while in the other cases, this group was removed with piperidine/DMF (3:7, $2+10 \mathrm{~min})$. After elongation of the peptide sequence and final Fmoc removal, an aliquot of the resulting resin was cleaved with TFA/ $\mathrm{H}_{2} \mathrm{O} / \mathrm{TIS}$ (95:2.5:2.5) while being stirred at room temperature for 2 or $3 \mathrm{~h}$. Following TFA evaporation and diethyl ether extraction, the crude peptide was dissolved in $\mathrm{H}_{2} \mathrm{O} / \mathrm{CH}_{3} \mathrm{CN}$ (1:1), lyophilized, analyzed by HPLC, and characterized by mass spectrometry.

Tailed Biaryl Cyclic Hexapeptidyl Resin 19. This peptidyl resin was prepared from the $\mathrm{N}$-methylated peptidyl resin 16 following the general method described above. Acidolytic cleavage of an aliquot of the resulting resin 19 for $2 \mathrm{~h}$ yielded the expected biaryl peptide in $85 \%$ purity. $t_{\mathrm{R}}=6.32 \mathrm{~min}$ (Conditions A). MS (ESI): $m / z=640.4[\mathrm{M}+\mathrm{H}]^{+}, 662.4[\mathrm{M}$ $+\mathrm{Na}]^{+}$

Tailed Biaryl Cyclic Hexapeptidyl Resin 20. This peptidyl resin was prepared from the $\mathrm{N}$-methylated peptidyl resin 17 following the general method described above. Acidolytic 
cleavage of an aliquot of the resulting resin 20 for $2 \mathrm{~h}$ yielded the expected biaryl peptide in $75 \%$ purity. $t_{\mathrm{R}}=6.07 \mathrm{~min}$ (Conditions A). MS (ESI): $m / z=670.3[\mathrm{M}+\mathrm{H}]^{+}, 692.2[\mathrm{M}$ $+\mathrm{Na}]^{+}$.

Regioisomeric Tailed Biaryl Cyclic Hexapeptidyl Resins 21. These regioisomeric peptidyl resins were prepared from the regioisomeric $\mathrm{N}$-methylated peptidyl resins $\mathbf{1 8}$ following the general method described above. Acidolytic cleavage of an aliquot of the resulting resins $\mathbf{2 1}$ for $3 \mathrm{~h}$ yielded the expected biaryl peptide in $18 \%$ purity. $t_{\mathrm{R}}=5.03 \mathrm{~min}$ (Conditions A). MS (ESI): $m / z=630.3[\mathrm{M}+\mathrm{H}]^{+}, 652.3[\mathrm{M}+\mathrm{Na}]^{+}$.

Synthesis of the N-Methylated Tailed Biaryl Cyclic Hexapeptidyl Resins 22-24. N-Methylation of peptidyl resins 19-21 was performed following the general procedure described for 16-18. After cleavage of an aliquot of the resulting $\mathrm{N}$-methylated resin for 2 or $3 \mathrm{~h}$, the crude peptide was analyzed by HPLC, characterized by mass spectrometry, and purified by reverse-phase column chromatography. Pure tailed biaryl cyclic peptides were analyzed by HPLC, and characterized by HRMS.

N-Methylated Tailed Biaryl Cyclic Hexapeptidyl Resin 22. $\mathrm{N}$-methylated peptidyl resin 22 was prepared from the peptidyl resin 19 following the general procedure described for 16-18. $o$ NBS protection: acidolytic cleavage for $2 \mathrm{~h}$ of an aliquot of the resulting resin afforded the expected peptide in $90 \%$ purity. $t_{\mathrm{R}}=7.10 \mathrm{~min}$ (Conditions A). MS (ESI): $m / z=825.3[\mathrm{M}+$ $\mathrm{H}]^{+}, 847.3[\mathrm{M}+\mathrm{Na}]^{+}$. Mitsunobu N-methylation: acidolytic cleavage for $2 \mathrm{~h}$ of an aliquot of the resulting resin afforded the expected peptide in $87 \%$ purity. $t_{\mathrm{R}}=7.26 \mathrm{~min}$ (Conditions $\mathrm{A}$ ). MS (ESI): $m / z=839.3[\mathrm{M}+\mathrm{H}]^{+}, 861.3[\mathrm{M}+\mathrm{Na}]^{+}$. oNBS group removal: acidolytic cleavage for $2 \mathrm{~h}$ of an aliquot of the resulting resin 22 afforded the expected $\mathrm{N}$-methylated tailed biaryl cyclic peptide 25 in $84 \%$ purity. $t_{\mathrm{R}}=6.39 \mathrm{~min}$ (Conditions A). MS (ESI): $m / z=654.3[\mathrm{M}+\mathrm{H}]^{+}, 676.3$ $[\mathrm{M}+\mathrm{Na}]^{+}$. Reverse-phase column chromatography and elution with $\mathrm{H}_{2} \mathrm{O} / \mathrm{CH}_{3} \mathrm{CN}$ (70:30) afforded the expected biaryl cyclic peptide 25 in $>99 \%$ purity. $t_{\mathrm{R}}=6.45 \mathrm{~min}$ (Conditions A). ${ }^{1} \mathrm{H}$ NMR (400 MHz, $\left.\mathrm{CD}_{3} \mathrm{OD}\right): \delta=7.38[\mathrm{dd}$, $J=1.6$ and $8.0 \mathrm{~Hz}, 1 \mathrm{H}, \mathrm{CH}_{\text {arom }} \mathrm{Phe}$ ], $7.29[\mathrm{dd}, J=1.6$ and 8.0 $\left.\mathrm{Hz}, 1 \mathrm{H}, \mathrm{CH}_{\text {arom }} \mathrm{Phe}\right], 7.25[\mathrm{dd}, J=1.6$ and $8.0 \mathrm{~Hz}, 1 \mathrm{H}$, $\mathrm{CH}_{\text {arom }} \mathrm{Phe}$ ], 7.15 [dd, $J=1.6$ and $8.0 \mathrm{~Hz}, 1 \mathrm{H}, \mathrm{CH}_{\text {arom }} \mathrm{Phe}$ ], $7.08\left[\mathrm{dd}, J=2.2\right.$ and $\left.8.4 \mathrm{~Hz}, 1 \mathrm{H}, \mathrm{CH}-6_{\text {arom }} \mathrm{Tyr}\right], 6.96[\mathrm{~d}, J=$ $\left.8.4 \mathrm{~Hz}, 1 \mathrm{H}, \mathrm{CH}-5_{\text {arom }} \mathrm{Tyr}\right], 6.79[\mathrm{~d}, J=2.2 \mathrm{~Hz}, 1 \mathrm{H}, \mathrm{CH}-$ $\left.2_{\text {arom }} \mathrm{Tyr}\right], 6.55[\mathrm{~d}, J=6.4 \mathrm{~Hz}, 1 \mathrm{H}, \mathrm{NH}], 4.89-4.84[\mathrm{~m}, 1 \mathrm{H}$, CH- $\alpha$ ], $4.53[\mathrm{q}, J=7.2 \mathrm{~Hz}, 1 \mathrm{H}, \mathrm{CH}-\alpha \mathrm{Ala}], 4.33-4.30[\mathrm{~m}, 1 \mathrm{H}$, $\mathrm{CH}-\alpha], 4.14[\mathrm{~d}, J=17.4 \mathrm{~Hz}, 1 \mathrm{H}, \mathrm{CH}-\alpha \mathrm{Gly}], 4.07$ [d, $J=17.4$ $\mathrm{Hz}, 1 \mathrm{H}, \mathrm{CH}-\alpha \mathrm{Gly}], 4.04-3.88$ [m, $\left.4 \mathrm{H}, 2 \mathrm{CH}-\alpha, \mathrm{CH}_{2}-\beta \mathrm{Ser}\right]$, $3.86\left[\mathrm{~s}, 3 \mathrm{H}, \mathrm{OCH}_{3}\right], 3.26\left[\mathrm{~s}, 3 \mathrm{H}, \mathrm{NCH}_{3}\right], 3.21-3.17[\mathrm{~m}, 1 \mathrm{H}$, $\mathrm{CH}-\beta], 2.96[\mathrm{dd}, J=4.8$ and $11.6 \mathrm{~Hz}, 1 \mathrm{H}, \mathrm{CH}-\beta], 2.92-2.87$ $[\mathrm{m}, 2 \mathrm{H}, \mathrm{CH}-\beta], 2.71\left[\mathrm{~s}, 3 \mathrm{H}, \mathrm{NHCH}_{3}\right], 1.42[\mathrm{~d}, J=7.2 \mathrm{~Hz}, 3 \mathrm{H}$, $\mathrm{CH}_{3}$-Ala $], 1.16$ [d, $\left.J=6.8 \mathrm{~Hz}, 3 \mathrm{H}, \mathrm{CH}_{3}-\mathrm{Ala}\right] \mathrm{ppm}$. MS (ESI): $m / z=654.3[\mathrm{M}+\mathrm{H}]^{+}, 676.3[\mathrm{M}+\mathrm{Na}]^{+}$. HRMS (ESI): calcd for $\mathrm{C}_{32} \mathrm{H}_{44} \mathrm{~N}_{7} \mathrm{O}_{8}[\mathrm{M}+\mathrm{H}]^{+}$654.3246, found 654.3241; calcd for $\mathrm{C}_{32} \mathrm{H}_{43} \mathrm{~N}_{7} \mathrm{O}_{8} \mathrm{Na}[\mathrm{M}+\mathrm{Na}]^{+}$676.3065, found 676.3058.

N-Methylated Tailed Biaryl Cyclic Hexapeptidyl Resin 23. $\mathrm{N}$-methylated tailed peptidyl resin 23 was prepared from the peptidyl resin 20 following the general procedure described for 16-18. oNBS protection: acidolytic cleavage for $2 \mathrm{~h}$ of an aliquot of the resulting resin afforded the expected peptide in $62 \%$ purity. $t_{\mathrm{R}}=6.92 \mathrm{~min}$ (Conditions A). MS (ESI): $\mathrm{m} / \mathrm{z}=$ 855.2 $[\mathrm{M}+\mathrm{H}]^{+}, 877.3[\mathrm{M}+\mathrm{Na}]^{+}$. Mitsunobu N-methylation: acidolytic cleavage for $2 \mathrm{~h}$ of an aliquot of the resulting resin afforded the expected peptide in $69 \%$ purity. $t_{\mathrm{R}}=7.13 \mathrm{~min}$
(Conditions A). MS (ESI): $m / z=869.3[\mathrm{M}+\mathrm{H}]^{+}, 891.3[\mathrm{M}$ $+\mathrm{Na}]^{+}$. oNBS group removal: acidolytic cleavage for $2 \mathrm{~h}$ of an aliquot of the resulting resin 23 afforded the expected $\mathrm{N}$ methylated tailed biaryl cyclic peptide 26 in $65 \%$ purity. $t_{\mathrm{R}}=$ $6.15 \mathrm{~min}$ (Conditions A). MS (ESI): $m / z=684.3[\mathrm{M}+\mathrm{H}]^{+}$, $706.3[\mathrm{M}+\mathrm{Na}]^{+}$. Reverse-phase column chromatography and elution with $\mathrm{H}_{2} \mathrm{O} / \mathrm{CH}_{3} \mathrm{CN}$ (75:25) afforded the expected biaryl cyclic peptide 26 in $78 \%$ purity. $t_{\mathrm{R}}=6.22 \mathrm{~min}$ (Conditions A). MS (ESI): $m / z=684.3[\mathrm{M}+\mathrm{H}]^{+}, 706.3$ $[\mathrm{M}+\mathrm{Na}]^{+}$. HRMS (ESI): calcd for $\mathrm{C}_{33} \mathrm{H}_{46} \mathrm{~N}_{7} \mathrm{O}_{9}[\mathrm{M}+\mathrm{H}]^{+}$ 684.3352, found 684.3342; calcd for $\mathrm{C}_{33} \mathrm{H}_{45} \mathrm{~N}_{7} \mathrm{O}_{9} \mathrm{Na}[\mathrm{M}+$ $\mathrm{Na}]^{+}$706.3171, found 706.3156.

N-Methylated Tailed Biaryl Cyclic Hexapeptidyl Resins 24. $\mathrm{N}-$ Methylated regioisomeric peptidyl resins 24 were prepared from the regioisomeric peptidyl resins $\mathbf{2 1}$ following the general procedure described for 16-18. oNBS protection: acidolytic cleavage for $3 \mathrm{~h}$ of an aliquot of the resulting resins afforded the expected peptide in $43 \%$ purity. $t_{\mathrm{R}}=6.00 \mathrm{~min}$ (Conditions A). MS (ESI): $m / z=815.3[\mathrm{M}+\mathrm{H}]^{+}, 837.2[\mathrm{M}+\mathrm{Na}]^{+}$. Mitsunobu N-methylation: acidolytic cleavage for $3 \mathrm{~h}$ of an aliquot of the resulting resins afforded the expected peptide in $49 \%$ purity. $t_{\mathrm{R}}=6.14 \mathrm{~min}$ (Conditions A). MS (ESI): $\mathrm{m} / z=$ 829.3 $[\mathrm{M}+\mathrm{H}]^{+}, 851.3[\mathrm{M}+\mathrm{Na}]^{+}$. oNBS group removal: acidolytic cleavage for $3 \mathrm{~h}$ of an aliquot of the resulting resins 24 afforded the expected $\mathrm{N}$-methylated tailed biaryl cyclic peptide 27 in $32 \%$ purity. $t_{\mathrm{R}}=5.30 \mathrm{~min}$ (Conditions A). MS (ESI): $m / z=644.3[\mathrm{M}+\mathrm{H}]^{+}, 666.2[\mathrm{M}+\mathrm{Na}]^{+}$. Reversephase column chromatography and elution with $\mathrm{H}_{2} \mathrm{O} / \mathrm{CH}_{3} \mathrm{CN}$ (98:2) afforded the expected biaryl cyclic peptide 27 in $50 \%$ purity. $t_{\mathrm{R}}=5.29 \mathrm{~min}$ (Conditions A). MS (ESI): $m / z=644.3$ $[\mathrm{M}+\mathrm{H}]^{+}, 666.3[\mathrm{M}+\mathrm{Na}]^{+}$. HRMS (ESI): calcd for $\mathrm{C}_{29} \mathrm{H}_{42} \mathrm{~N}_{9} \mathrm{O}_{8}[\mathrm{M}+\mathrm{H}]^{+}$644.3151, found 644.3129; calcd for $\mathrm{C}_{29} \mathrm{H}_{41} \mathrm{~N}_{9} \mathrm{O}_{8} \mathrm{Na}[\mathrm{M}+\mathrm{Na}]^{+}$666.2970, found 666.2954.

Synthesis of Tailed Biaryl Cyclic Lipohexapeptides 1-3. General Method for the Solid-Phase Peptide Acylation of N-Methylated Tailed Biaryl Cyclic Lipopeptidyl Resins. A solution of palmitic acid (4 equiv), DIPCDI (4 equiv), and Oxyma (4 equiv) in DMF was added to the corresponding $\mathrm{N}$ methylated tailed biaryl cyclic peptidyl resin 22-24. The reaction mixture was stirred overnight at room temperature. After acylation, the resulting resin was washed with DMF $(6 \times$ $1 \mathrm{~min}), \mathrm{CH}_{2} \mathrm{Cl}_{2}(3 \times 1 \mathrm{~min})$, and diethyl ether $(3 \times 1 \mathrm{~min})$, and the completion of the reaction was then checked using the chloranil test. ${ }^{45}$ Upon completion of the acylation, a solution of TFA $/ \mathrm{H}_{2} \mathrm{O} / \mathrm{TIS}$ (95:2.5:2.5) was added to the resin and the mixture was stirred at room temperature for 2 or $3 \mathrm{~h}$. TFA evaporation and diethyl ether extraction gave the corresponding crude peptide mixture, which was dissolved in $\mathrm{H}_{2} \mathrm{O}$ / $\mathrm{CH}_{3} \mathrm{CN}$ (1:1), lyophilized, and characterized by mass spectrometry.

Tailed Biaryl Cyclic Lipohexapeptide 1. This peptide was prepared from resin $\mathbf{2 2}$ following the method described above. Acidolytic cleavage of an aliquot of the resulting lipopeptidyl resin for $2 \mathrm{~h}$ gave traces of the expected tailed biaryl cyclic lipopeptide 1. HRMS (ESI): calcd for $\mathrm{C}_{48} \mathrm{H}_{74} \mathrm{~N}_{7} \mathrm{O}_{9}[\mathrm{M}+\mathrm{H}]^{+}$ 892.5543, found 892.5549.

Tailed Biaryl Cyclic Lipohexapeptide 2. This peptide was prepared from resin $\mathbf{2 3}$ following the method described above. Acidolytic cleavage of an aliquot of the resulting lipopeptidyl resin for $2 \mathrm{~h}$ gave traces of the expected tailed biaryl cyclic lipopeptide 2. MS (ESI): $m / z=922.6[\mathrm{M}+\mathrm{H}]^{+}$.

Tailed Biaryl Cyclic Lipohexapeptide 3. This peptide was prepared from resins $\mathbf{2 4}$ following the method described above. 
Acidolytic cleavage of an aliquot of the resulting lipopeptidyl resins for $3 \mathrm{~h}$ gave traces of the expected tailed biaryl cyclic lipopeptide 3. HRMS (ESI): calcd for $\mathrm{C}_{45} \mathrm{H}_{72} \mathrm{~N}_{9} \mathrm{O}_{9}[\mathrm{M}+\mathrm{H}]^{+}$ 882.5448, found 882.5468.

Synthesis of Tailed Biaryl Cyclic Lipoheptapeptides 31-33. General Method for the Solid-Phase Peptide Synthesis of Tailed Biaryl Cyclic Lipoheptapeptidyl Resins. A solution of Fmoc-Lys(Boc)-OH (4 equiv), DIPCDI (4 equiv), and Oxyma (4 equiv) in DMF was added to the corresponding $\mathrm{N}$-methylated resins 22-24. The reaction mixture was stirred overnight at room temperature. Then, the resulting resin was washed with DMF $(6 \times 1 \mathrm{~min}), \mathrm{CH}_{2} \mathrm{Cl}_{2}$ ( $3 \times 1 \mathrm{~min})$, and diethyl ether $(3 \times 1 \mathrm{~min})$, and the completion of the reaction was checked using the chloranil test. ${ }^{45}$ An aliquot of the resulting resin was cleaved with TFA/ $\mathrm{H}_{2} \mathrm{O}$ /TIS (95:2.5:2.5) for 2 or $3 \mathrm{~h}$. The crude reaction mixture was analyzed by HPLC and characterized by mass spectrometry.

Then, the Fmoc group was removed with piperidine/DMF $(3: 7,2+10+10 \mathrm{~min})$ followed by washes with DMF $(6 \times 1$ $\mathrm{min})$. The resulting resin was treated with a solution of palmitic acid (4 equiv), DIPCDI (4 equiv), and Oxyma (4 equiv) in DMF, and the reaction mixture was stirred overnight at room temperature. Then, the resin was washed with DMF $(6 \times 1 \mathrm{~min}), \mathrm{CH}_{2} \mathrm{Cl}_{2}(3 \times 1 \mathrm{~min})$, and diethyl ether $(3 \times 1$ min), and the completion of the reaction was checked using the Kaiser test. ${ }^{44}$ Upon completion of the acylation, a solution of TFA/ $\mathrm{H}_{2} \mathrm{O} / \mathrm{TIS}$ (95:2.5:2.5) was added and the mixture was stirred at room temperature for 2 or $3 \mathrm{~h}$. Following TFA evaporation and diethyl ether extraction, the crude peptide was dissolved in $\mathrm{H}_{2} \mathrm{O} / \mathrm{CH}_{3} \mathrm{CN}$ (1:1), lyophilized, and characterized by mass spectrometry. Tailed biaryl cyclic lipoheptapeptides were purified by reverse-phase column chromatography.

Tailed Biaryl Cyclic Lipoheptapeptide 31. This biaryl peptide was prepared from peptidyl resin 22 as described above. After coupling of Fmoc-Lys(Boc)-OH, acidolytic cleavage of an aliquot of the resulting resin 28 for $2 \mathrm{~h}$ afforded the expected biaryl peptide in $81 \%$ purity. $t_{\mathrm{R}}=7.36 \mathrm{~min}$ (Conditions A). MS (ESI): $m / z=1004.6[\mathrm{M}+\mathrm{H}]^{+}, 1026.5$ $[\mathrm{M}+\mathrm{Na}]^{+}$. Coupling of palmitic acid and acidolytic cleavage for $2 \mathrm{~h}$ afforded the expected biaryl cyclic palmitoyl peptide 31 in $69 \%$ purity. $t_{\mathrm{R}}=9.13 \mathrm{~min}$ (Conditions A). MS (ESI): $\mathrm{m} / z=$ $1020.7[\mathrm{M}+\mathrm{H}]^{+}, 1042.7[\mathrm{M}+\mathrm{Na}]^{+}$. Elution with $\mathrm{H}_{2} \mathrm{O} /$ $\mathrm{CH}_{3} \mathrm{CN}(55: 45)$ yielded pure 31 in $97 \%$ purity. $t_{\mathrm{R}}=9.18 \mathrm{~min}$ (Conditions A). ${ }^{1} \mathrm{H}$ NMR (400 MHz, $\left.\mathrm{CD}_{3} \mathrm{OD}\right): \delta=7.37[\mathrm{dd}$, $J=1.4$ and $\left.8.0 \mathrm{~Hz}, 1 \mathrm{H}, \mathrm{CH}-5^{\prime}{ }_{\text {arom }} \mathrm{Phe}\right], 7.30-7.25[\mathrm{~m}, 2 \mathrm{H}$, $\mathrm{CH}-3^{\prime}{ }_{\text {arom }}$ Phe, CH- ${ }^{\prime}{ }_{\text {arom }}$ Phe $], 7.16[\mathrm{dd}, J=1.6$ and $7.6 \mathrm{~Hz}$, $1 \mathrm{H}, \mathrm{CH}-2^{\prime}{ }_{\text {arom }} \mathrm{Phe}$ ], 7.08 [dd, $J=2.2$ and $8.4 \mathrm{~Hz}, 1 \mathrm{H}, \mathrm{CH}-$ $\left.6_{\text {arom }} \mathrm{Tyr}\right], 6.96\left[\mathrm{~d}, J=8.4 \mathrm{~Hz}, 1 \mathrm{H}, \mathrm{CH}-5_{\text {arom }} \mathrm{Tyr}\right], 6.79[\mathrm{~d}, J=$ $\left.2.2 \mathrm{~Hz}, 1 \mathrm{H}, \mathrm{CH}-2_{\text {arom }} \mathrm{Tyr}\right], 4.93-4.89[\mathrm{~m}, 2 \mathrm{H}, 2 \mathrm{CH}-\alpha], 4.43$ [q, $J=7.2 \mathrm{~Hz}, 1 \mathrm{H}, \mathrm{CH}-\alpha \mathrm{Ala}], 4.32[\mathrm{dd}, J=3.6$ and $9.6 \mathrm{~Hz}$, $1 \mathrm{H}, \mathrm{CH}-\alpha], 4.17-3.97$ [m, $6 \mathrm{H}, 4 \mathrm{CH}-\alpha, 2 \mathrm{CH}-\beta \mathrm{Ser}], 3.86[\mathrm{~s}$, $\left.3 \mathrm{H}, \mathrm{OCH}_{3}\right], 3.25\left[\mathrm{~s}, 3 \mathrm{H}, \mathrm{NCH}_{3}\right], 3.23-3.20[\mathrm{~m}, 1 \mathrm{H}, \mathrm{CH}-\beta]$, 3.19 [s, $3 \mathrm{H}, \mathrm{NCH}_{3}$ ] $2.93-2.87\left[\mathrm{~m}, 5 \mathrm{H}, 3 \mathrm{CH}-\beta, \mathrm{CH}_{2}-\varepsilon \mathrm{Lys}\right]$, $2.24\left[\mathrm{t}, J=7.2 \mathrm{~Hz}, 2 \mathrm{H}, \mathrm{CH}_{2}-\alpha \mathrm{Palm}\right], 1.81-1.78\left[\mathrm{~m}, 2 \mathrm{H}, \mathrm{CH}_{2}-\right.$ $\beta$ Lys $], 1.68-1.66\left[\mathrm{~m}, 2 \mathrm{H}, \mathrm{CH}_{2}-\delta \mathrm{Lys}\right], 1.61-1.57[\mathrm{~m}, 2 \mathrm{H}$, $\mathrm{CH}_{2}-\beta$ Palm $], 1.40\left[\mathrm{~d}, J=7.2 \mathrm{~Hz}, 3 \mathrm{H}, \mathrm{CH}_{3}-\mathrm{Ala}\right.$ ], $1.30-1.24$ $\left[\mathrm{m}, 26 \mathrm{H}, 12 \mathrm{CH}_{2}-\mathrm{Palm}, \mathrm{CH}_{2}-\gamma \mathrm{Lys}\right], 1.16[\mathrm{~d}, J=6.8 \mathrm{~Hz}, 3 \mathrm{H}$, $\mathrm{CH}_{3}-\mathrm{Ala}$ ], $0.90\left[\mathrm{t}, J=6.4 \mathrm{~Hz}, 3 \mathrm{H}, \mathrm{CH}_{3}-\mathrm{Palm}\right] \mathrm{ppm}$. MS (ESI): $m / z=1020.7[\mathrm{M}+\mathrm{H}]^{+}, 1042.7[\mathrm{M}+\mathrm{Na}]^{+}$. HRMS (ESI): calcd for $\mathrm{C}_{54} \mathrm{H}_{86} \mathrm{~N}_{9} \mathrm{O}_{10}[\mathrm{M}+\mathrm{H}]^{+} 1020.6492$, found 1020.6468; calcd for $\mathrm{C}_{54} \mathrm{H}_{85} \mathrm{~N}_{9} \mathrm{O}_{10} \mathrm{Na}[\mathrm{M}+\mathrm{Na}]^{+}$1042.6312, found 1042.6281 .
Tailed Biaryl Cyclic Lipoheptapeptide 32. This biaryl peptide was prepared from peptidyl resin 23 as described above. After subsequent couplings of Fmoc-Lys(Boc)-OH and palmitic acid, acidolytic cleavage for $2 \mathrm{~h}$ afforded the expected biaryl cyclic palmitoyl peptide 32 in $51 \%$ purity. $t_{\mathrm{R}}=8.69 \mathrm{~min}$ (Conditions A). MS (ESI): $m / z 1050.7[\mathrm{M}+\mathrm{H}]^{+}, 1072.7[\mathrm{M}$ $+\mathrm{Na}]^{+}$. Elution with $\mathrm{H}_{2} \mathrm{O} / \mathrm{CH}_{3} \mathrm{CN}(50: 50)$ yielded pure 32 in $96 \%$ purity. $t_{\mathrm{R}}=8.67 \mathrm{~min}$ (Conditions A). ${ }^{1} \mathrm{H}$ NMR (400 $\left.\mathrm{MHz}, \mathrm{CD}_{3} \mathrm{OD}\right): \delta=7.29-7.13\left[\mathrm{~m}, 3 \mathrm{H}, 3 \mathrm{CH}_{\text {arom }} \mathrm{Tyr}\right], 6.95-$ $6.68\left[\mathrm{~m}, 3 \mathrm{H}, 3 \mathrm{CH}_{\text {arom }} \mathrm{Tyr}\right], 4.95-4.91[\mathrm{~m}, 1 \mathrm{H}, \mathrm{CH}-\alpha \mathrm{Ser}]$, $4.83-4.72\left[\mathrm{~m}, 4 \mathrm{H}, \mathrm{CH}-\alpha \mathrm{Ala}, \mathrm{CH}-\alpha \mathrm{Tyr}^{\mathrm{b}}, \mathrm{CH}-\alpha \mathrm{Lys}\right], 4.50-$ $4.44\left[\mathrm{~m}, 2 \mathrm{H}, \mathrm{CH}-\alpha \mathrm{Ala}, \mathrm{CH}-\alpha \mathrm{Tyr}^{\mathrm{a}}\right], 4.12-4.08[\mathrm{~m}, 1 \mathrm{H}, \mathrm{CH}-$ $\beta$ Ser $]$, 3.96-3.91 [m, $1 \mathrm{H}, \mathrm{CH}-\beta \mathrm{Ser}], 3.78-3.73[\mathrm{~m}, 8 \mathrm{H}, \mathrm{CH}-$ $\alpha$ Gly, $\left.2 \mathrm{OCH}_{3}\right], 3.37\left[\mathrm{~s}, 3 \mathrm{H}, \mathrm{NCH}_{3}\right], 3.22\left[\mathrm{~s}, 3 \mathrm{H}, \mathrm{NCH}_{3}\right]$, $3.16-3.13\left[\mathrm{~m}, 1 \mathrm{H}, \mathrm{CH}-\beta \mathrm{Tyr}^{\mathrm{b}}\right], 3.10-3.04[\mathrm{~m}, 1 \mathrm{H}, \mathrm{CH}-$ $\beta \mathrm{Tyr}^{\mathrm{a}}$ ], 2.98-2.89 [m, 2H, $\left.\mathrm{CH}_{2}-\varepsilon \mathrm{Lys}\right], 2.84-2.75[\mathrm{~m}, 1 \mathrm{H}$, $\mathrm{CH}-\beta \mathrm{Tyr}^{\mathrm{b}}$ ], $2.29-2.18\left[\mathrm{~m}, 2 \mathrm{H}, \mathrm{CH}_{2}-\alpha \mathrm{Palm}\right], 1.90-1.81[\mathrm{~m}$, $2 \mathrm{H}, \mathrm{CH}_{2}-\beta \mathrm{Lys}$ ], $1.73-1.58$ [m, $4 \mathrm{H}, \mathrm{CH}_{2}-\beta \mathrm{Palm}, \mathrm{CH}_{2}-\delta \mathrm{Lys}$, 1.47-1.27 [m, 32H, $12 \mathrm{CH}_{2}$-Palm, $2 \mathrm{CH}_{3}$-Ala, $\left.\mathrm{CH}_{2}-\gamma \mathrm{Lys}\right]$, $0.92\left[\mathrm{t}, J=6.3 \mathrm{~Hz}, 3 \mathrm{H}, \mathrm{CH}_{3}-\mathrm{Palm}\right] \mathrm{ppm}$. MS (ESI): $\mathrm{m} / z=$ $1050.7[\mathrm{M}+\mathrm{H}]^{+}$. HRMS (ESI): calcd for $\mathrm{C}_{55} \mathrm{H}_{88} \mathrm{~N}_{9} \mathrm{O}_{11} \mathrm{Na}[\mathrm{M}$ $+\mathrm{Na}+\mathrm{H}]^{2+} 536.8245$, found 536.8225; calcd for $\mathrm{C}_{55} \mathrm{H}_{88} \mathrm{~N}_{9} \mathrm{O}_{11}[\mathrm{M}+\mathrm{H}]^{+}$1050.6598, found 1050.6564 .

Tailed Biaryl Cyclic Lipoheptapeptide 33. This biaryl peptide was prepared from peptidyl resins 24 as described above. After coupling of Fmoc-Lys(Boc)-OH, acidolytic cleavage of an aliquot of the resulting resins 30 for $3 \mathrm{~h}$ afforded the expected biaryl peptide in $40 \%$ purity. $t_{\mathrm{R}}=6.54$ min (Conditions A). MS (ESI): $m / z=994.5[\mathrm{M}+\mathrm{H}]^{+}$. Coupling of palmitic acid and acidolytic cleavage for $3 \mathrm{~h}$ afforded the expected biaryl cyclic palmitoyl peptide 33 in 34\% purity. $t_{\mathrm{R}}=7.80 \mathrm{~min}$ (Conditions A). MS (ESI): $m / z=1010.8$ $[\mathrm{M}+\mathrm{H}]^{+}, 1032.7[\mathrm{M}+\mathrm{Na}]^{+}$. HRMS (ESI): calcd for $\mathrm{C}_{51} \mathrm{H}_{85} \mathrm{~N}_{11} \mathrm{O}_{10}[\mathrm{M}+2 \mathrm{H}]^{2+}$ 505.8235, found 505.8226; calcd for $\mathrm{C}_{51} \mathrm{H}_{84} \mathrm{~N}_{11} \mathrm{O}_{10}[\mathrm{M}+\mathrm{H}]^{+}$1010.6397, found 1010.6395. Elution with $\mathrm{H}_{2} \mathrm{O} / \mathrm{CH}_{3} \mathrm{CN}$ (55:45) yielded pure 33 in $87 \%$ purity. $t_{\mathrm{R}}=7.83 \mathrm{~min}$ (Conditions A). MS (ESI): $\mathrm{m} / z=505.8$ $[\mathrm{M}+2 \mathrm{H}]^{2+}, 1010.7[\mathrm{M}+\mathrm{H}]^{+}, 1032.7[\mathrm{M}+\mathrm{Na}]^{+}$. HRMS (ESI): calcd for $\mathrm{C}_{51} \mathrm{H}_{85} \mathrm{~N}_{11} \mathrm{O}_{10}[\mathrm{M}+2 \mathrm{H}]^{2+}$ 505.8235, found 505.8216; calcd for $\mathrm{C}_{51} \mathrm{H}_{84} \mathrm{~N}_{11} \mathrm{O}_{10} \mathrm{Na}[\mathrm{M}+\mathrm{Na}+\mathrm{H}]^{2+}$ 516.8145, found 516.8128; calcd for $\mathrm{C}_{51} \mathrm{H}_{84} \mathrm{~N}_{11} \mathrm{O}_{10}[\mathrm{M}+$ $\mathrm{H}]^{+}$1010.6397, found 1010.6403; calcd for $\mathrm{C}_{51} \mathrm{H}_{83} \mathrm{~N}_{11} \mathrm{O}_{10} \mathrm{Na}$ $[\mathrm{M}+\mathrm{Na}]^{+}$1032.6217, found 1032.6212 .

\section{ASSOCIATED CONTENT}

\section{Supporting Information}

The Supporting Information is available free of charge at https://pubs.acs.org/doi/10.1021/acsomega.0c03352.

HPLC and mass spectrometry of linear peptides, biaryl cyclic peptides, and biaryl cyclic lipopeptides. 1D and 2D NMR of biaryl cyclic tripeptides 13-15, Nmethylated tailed biaryl cyclic hexapeptide 25, and tailed biaryl cyclic lipoheptapeptides 31 and 32 (PDF)

\section{AUTHOR INFORMATION}

\section{Corresponding Authors}

Lidia Feliu - LIPPSO, Department of Chemistry, University of

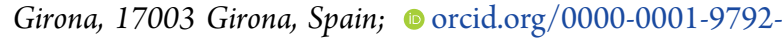
6106; Email: lidia.feliu@udg.edu

Marta Planas - LIPPSO, Department of Chemistry, University of Girona, 17003 Girona, Spain; 이이이.org/0000-00034988-4970; Email: marta.planas@udg.edu 


\section{Authors \\ Iteng Ng-Choi - LIPPSO, Department of Chemistry, University of Girona, 17003 Girona, Spain \\ Eduard Figueras - LIPPSO, Department of Chemistry, University of Girona, 17003 Girona, Spain; 이이. orcid.org/ 0000-0002-1853-9974 \\ Àngel Oliveras - LIPPSO, Department of Chemistry, University of Girona, 17003 Girona, Spain}

Complete contact information is available at: https://pubs.acs.org/10.1021/acsomega.0c03352

\section{Notes}

The authors declare no competing financial interest.

\section{ACKNOWLEDGMENTS}

I.N.-C. is a recipient of a predoctoral fellowship from the MICINN of Spain and À.O. of one from the University of Girona. This work was supported by Grants AGL2009-13255C02-02/AGR，AGL2012-39880-C02-02/AGR, MPCUdG2016/038, and RTI2018-099410-B-C22 (MCIU/ AEI/FEDER, EU). The authors acknowledge the Serveis Tècnics de Recerca of the University of Girona for the mass spectrometry analysis and the NMR experiments.

\section{REFERENCES}

(1) Feliu, L.; Planas, M. Cyclic Peptides Containing Biaryl and Biaryl Ether Linkages. Int. J. Pept. Res. Ther. 2005, 11, 53-97.

(2) Zorzi, A.; Deyle, K.; Heinis, C. Cyclic Peptide Therapeutics: Past, Present and Future. Curr. Opin. Chem. Biol. 2017, 38, 24-29.

(3) Schimana, J.; Gebhardt, K.; Höltzel, A.; Schmid, D. G.; Süssmuth, R.; Müller, J.; Pukall, R.; Fiedler, H. Arylomycins A and B, New Biaryl-Bridged Lipopeptide Antibiotics Produced by Streptomyces Sp. Tü 6075. I. Taxonomy, Fermentation, Isolation and Biological Activities. J. Antibiot. 2002, 55, 565-570.

(4) Roberts, T. C.; Smith, P. A.; Cirz, R. T.; Romesberg, F. E. Structural and Initial Biological Analysis of Synthetic Arylomycin A2. J. Am. Chem. Soc. 2007, 129, 15830-15838.

(5) Roberts, T. C.; Smith, P. A.; Romesberg, F. E. Synthesis and Biological Characterization of Arylomycin B Antibiotics. J. Nat. Prod. 2011, 74, 956-961.

(6) Liu, J.; Luo, C.; Smith, P. A.; Chin, J. K.; Page, M. G. P.; Paetzel, M.; Romesberg, F. E. Synthesis and Characterization of the Arylomycin Lipoglycopeptide Antibiotics and the Crystallographic Analysis of Their Complex with Signal Peptidase. J. Am. Chem. Soc. 2011, 133, 17869-17877.

(7) Smith, P. A.; Roberts, T. C.; Romesberg, F. E. Broad-spectrum Antibiotic Activity of the Arylomycin Natural Products Is Masked by Natural Target Mutations. Chem. Biol. 2010, 17, 1223-1231.

(8) Smith, P. A.; Powers, M. E.; Roberts, T. C.; Romesberg, F. E. In Vitro Activities of Arylomycin Natural-Product Antibiotics Against Staphylococcus Epidermidis and Other Coagulase-Negative Staphylococci. Antimicrob. Agents Chemother. 2011, 55, 1130-1134.

(9) Tan, Y. X.; Romesberg, F. E. Latent Antibiotics and the Potential of the Arylomycins for Broad-Spectrum Antibacterial Activity. Med. Chem. Commun. 2012, 3, 916-925.

(10) Craney, A.; Romesberg, F. E. A Putative Cro-Like Repressor Contributes to Arylomycin Resistance in Staphylococcus aureus. Antimicrob. Agents Chemother. 2015, 59, 3066-3074.

(11) Steed, D. B.; Liu, J.; Wasbrough, E.; Miller, L.; Halasohoris, S.; Miller, J.; Somerville, B.; Hershfield, J. R.; Romesberg, F. E. Origins of Yersinia pestis Sensitivity to the Arylomycin Antibiotics and the Inhibition of Type I Signal Peptidase. Antimicrob. Agents Chemother. 2015, 59, 3887-3898.

(12) Walsh, S. I.; Peters, D. S.; Smith, P. A.; Craney, A.; Dix, M. M.; Cravatt, B. F.; Romesberg, F. E. Inhibition of Protein Secretion in
Escherichia coli and Sub-MIC Effects of Arylomycin Antibiotics. Antimicrob. Agents Chemother. 2019, 63, No. e01253-18.

(13) Dufour, J.; Neuville, L.; Zhu, J. Total Synthesis of Arylomycin $\mathrm{A}_{2}$, a Signal Peptidase I (SPase I) Inhibitor. Synlett 2008, 15, 23552359.

(14) Dufour, J.; Neuville, L.; Zhu, J. Intramolecular Suzuki-Miyaura Reaction for the Total Synthesis of Signal Peptidase Inhibitors, Arylomycins $\mathrm{A}_{2}$ and $\mathrm{B}_{2}$. Chem. - Eur. J. 2010, 16, 10523-10534.

(15) Roberts, T. C.; Schallenberger, M. A.; Liu, J.; Smith, P. A.; Romesberg, F. E. Initial Efforts Toward the Optimization of Arylomycins for Antibiotic Activity. J. Med. Chem. 2011, 54, 49544963.

(16) Liu, J.; Smith, P. A.; Steed, D. B.; Romesberg, F. E. Efforts Toward Broadening the Spectrum of Arylomycin Antibiotic Activity. Bioorg. Med. Chem. Lett. 2013, 23, 5654-5659.

(17) Peters, D. S.; Romesberg, F. E.; Baran, P. S. Scalable Access to Arylomycins via $\mathrm{C}-\mathrm{H}$ Functionalization Logic. J. Am. Chem. Soc. 2018, 140, 2072-2075.

(18) Smith, P. A.; Koehler, M. F. T.; Girgis, H. S.; Yan, D.; Chen, Y.; Chen, Y.; Crawford, J. J.; Durk, M. R.; Higuchi, R. I.; Kang, J.; Murray, J.; Paraselli, P.; Park, S.; Phung, W.; Quinn, J. G.; Roberts, T. C.; Rougé, L.; Schwarz, J. B.; Skippington, E.; Wai, J.; Xu, M.; Yu, Z.; Zhang, H.; Tan, M.-W.; Heise, C. E. Optimized Arylomycins Are a New Class of Gram-Negative Antibiotics. Nature 2018, 561, 189194

(19) Lim, N.-K.; Linghu, X.; Wong, N.; Zhang, H.; Sowell, G.; Gosselin, F. Macrolactamization Approaches to Arylomycin Antibiotics Core. Org. Lett. 2019, 21, 147-151.

(20) Wong, N.; Petronijević, F.; Hong, A. Y.; Linghu, X.; Kelly, S. M.; Hou, H.; Cravillion, T.; Lim, N.-K.; Robinson, S. J.; Han, C.; Molinaro, C.; Sowell, C. G.; Gosselin, F. Stereocontrolled Synthesis of Arylomycin-Based Gram-Negative Antibiotic GDC-5338. Org. Lett. 2019, 21, 9099-9103.

(21) Ben-Lulu, M.; Gaster, E.; Libman, A.; Pappo, D. Synthesis of Biaryl-Bridged Cyclic Peptides via Catalytic Oxidative Cross-Coupling Reactions. Angew. Chem., Int. Ed. 2020, 59, 4835-4839.

(22) Jaradat, D. M. M. Thirteen Decades of Peptide Synthesis: Key Developments in Solid Phase Peptide Synthesis and Amide Bond Formation Utilized in Peptide Ligation. Amino Acids 2018, 50, 39-68.

(23) Nielsen, T. E.; Le Quement, S.; Meldal, M. Solid-Phase Synthesis of Biarylalanines via Suzuki Cross-Coupling and Intramolecular N-Acyliminium Pictet-Spengler Reactions. Tetrahedron Lett. 2005, 46, 7959-7962.

(24) Haug, B. E.; Stensen, W.; Svendsen, J. S. Application of the Suzuki-Miyaura Cross-Coupling to Increase Antimicrobial Potency Generates Promising Novel Antibacterials. Bioorg. Med. Chem. Lett. 2007, 17, 2361-2364.

(25) Doan, N.; Bourgault, S.; Létourneau, M.; Fournier, A. Effectiveness of the Suzuki-Miyaura Cross-Coupling Reaction for Solid-Phase Peptide Modification. J. Comb. Chem. 2008, 10, 44-51.

(26) Le Quement, S. T.; Ishoey, M.; Petersen, M. T.; Thastrup, J.; Hagel, G.; Nielsen, T. E. Solid-Phase Synthesis of Smac Peptidomimetics Incorporating Triazoloprolines and Biarylalanines. ACS Comb. Sci. 2011, 13, 667-675.

(27) Meyer, F.; Collins, J. C.; Borin, B.; Bradow, J.; Liras, S.; Limberakis, C.; Mathiowetz, A. M.; Philippe, L.; Price, D.; Song, K.; James, K. Biaryl-Bridged Macrocyclic Peptides: Conformational Constraint via Carbogenic Fusion of Natural Amino Acid Side Chains. J. Org. Chem. 2012, 77, 3099-3114.

(28) Qiao, J. X.; Fraunhoffer, K. J.; Hsiao, Y.; Li, Y.-X.; Wang, C.; Wang, T. C.; Poss, M. A. Synthesis of Fmoc-Protected Arylphenylalanines (Bip Derivatives) via Nonaqueous Suzuki-Miyaura CrossCoupling Reactions. J. Org. Chem. 2016, 81, 9499-9506.

(29) Willemse, T.; Schepens, W.; van Vlijmen, H. W. T.; Maes, B. U. W.; Ballet, S. The Suzuki-Miyaura Cross-Coupling as a Versatile Tool for Peptide Diversification and Cyclization. Catalysts 2017, 7, No. 74.

(30) Cerezo, V.; Amblard, M.; Martinez, J.; Verdié, P.; Planas, M.; Feliu, L. Solid-Phase Synthesis of 5-Arylhistidines via a Microwave- 
Assisted Suzuki-Miyaura Cross-Coupling. Tetrahedron 2008, 64, 10538-10545.

(31) Afonso, A.; Rosés, C.; Planas, M.; Feliu, L. Biaryl Peptides from 4-Iodophenylalanine by Solid-Phase Borylation and Suzuki-Miyaura Cross-Coupling. Eur. J. Org. Chem. 2010, 2010, 1461-1468.

(32) Afonso, A.; Feliu, L.; Planas, M. Solid-Phase Synthesis of Biaryl Cyclic Peptides by Borylation and Microwave-Assisted Intramolecular Suzuki-Miyaura Reaction. Tetrahedron 2011, 67, 2238-2245.

(33) Ng-Choi, I.; Soler, M.; Cerezo, V.; Badosa, E.; Montesinos, E.; Planas, M.; Feliu, L. Solid-Phase Synthesis of 5-ArylhistidineContaining Peptides with Antimicrobial Activity Through a Microwave-Assisted Suzuki-Miyaura Cross-Coupling. Eur. J. Org. Chem. 2012, 2012, 4321-4332.

(34) Afonso, A.; Cussó, O.; Feliu, L.; Planas, M. Solid-Phase Synthesis of Biaryl Cyclic Peptides Containing a 3-Aryltyrosine. Eur. J. Org. Chem. 2012, 2012, 6204-6211.

(35) Ng-Choi, I.; Oliveras, À.; Planas, M.; Feliu, L. Solid-Phase Synthesis of Biaryl Cyclic Peptides Containing a Histidine-Tyrosine Linkage. Tetrahedron 2019, 75, 2625-2636.

(36) Ng-Choi, I.; Oliveras, À.; Feliu, L.; Planas, M. Solid-Phase Synthesis of Biaryl Cyclic Peptides Containing a Histidine-Phenylalanine Linkage. Int. J. Pept. Res. Ther. 2020, 26, 695-707.

(37) Lei, H.; Stoakes, M.; Herath, K. P. B.; Lee, J.; Schwabacher, A. W. Efficient Synthesis of a Phosphinate Bis-Amino Acid and Its Use in the Construction of Amphiphilic Peptides. J. Org. Chem. 1994, 59, 4206-4210.

(38) Prieto, M.; Mayor, S.; Lloyd-Williams, P.; Giralt, E. Use of the SPhos Ligand to Suppress Racemization in Arylpinacolboronate Ester Suzuki Couplings Involving $\alpha$-Amino Acids. Synthesis of Biaryl Derivatives of 4-Hydroxyphenylglycine, Tyrosine, and Tryptophan. J. Org. Chem. 2009, 74, 9202-9205.

(39) Lennox, A. J. J.; Lloyd-Jones, G. C. Selection of Boron Reagents for Suzuki-Miyaura Coupling. Chem. Soc. Rev. 2014, 43, 412-443.

(40) Zhang, A. J.; Russell, D. H.; Zhu, J. P.; Burguess, K. A Method for Removal of N-BOC Protecting Groups from Substrates on TFASensitive Resins. Tetrahedron Lett. 1998, 39, 7439-7442.

(41) Yang, L.; Chiu, K. Solid Phase Synthesis of Fmoc N-Methyl Amino Acids: Application of the Fukuyama Amine Synthesis. Tetrahedron Lett. 1997, 38, 7307-7310.

(42) Miller, S. C.; Scanlan, T. S. oNBS-SPPS: A New Method for Solid-Phase Peptide Synthesis. J. Am. Chem. Soc. 1998, 120, 26902691.

(43) Tulla-Puche, J.; Auriemma, S.; Falciani, C.; Albericio, F. Orthogonal Chemistry for the Synthesis of Thiocoraline-Triostin Hybrids. Exploring their Structure-Activity Relationship. J. Med. Chem. 2013, 56, 5587-5600.

(44) Kaiser, E.; Colescott, R. L.; Bossinger, C. D.; Cook, P. Color Test for Detection of Free Terminal Amino Groups in the SolidPhase Synthesis of Peptides. Anal. Biochem. 1970, 34, 595-598.

(45) Vojkovsky, T. Detection of Secondary Amines on Solid Phase. Pept. Res. 1995, 8, 236-237. 